\title{
19. LITHOLOGY, MINERALOGY, AND ORIGIN OF SERPENTINE MUDS RECOVERED FROM CONICAL AND TORISHIMA FOREARC SEAMOUNTS: RESULTS OF LEG 125 DRILLING ${ }^{1}$
}

\author{
Patricia Fryer ${ }^{2}$ and Michael J. Mottl ${ }^{3}$
}

\begin{abstract}
Large serpentinite seamounts are common in the forearc regions between the trench axis and the active volcanic fronts of the Mariana and Izu-Bonin intraoceanic arcs. The seamounts apparently form both as mud volcanoes, composed of unconsolidated serpentine mud flows that have entrained metamorphosed ultramafic and mafic rocks, and as horst blocks, possibly diapirically emplaced, of serpentinized ultramafics partially draped with unconsolidated serpentine slump deposits and mud flows. The clayand silt-sized serpentine recovered from three sites on Conical Seamount on the Mariana forearc region and from two sites on Torishima Forearc Seamount on the Izu-Bonin forearc region is composed predominantly of chrysotile, brucite, chlorite, and clays. A variety of accessory minerals attest to the presence of unusual pore fluids in some of the samples. Aragonite, unstable at the depths at which the serpentine deposits were drilled, is present in many of the surficial cores from Conical Seamount. Sjogrenite minerals, commonly found as weathering products of serpentine resulting from interaction with groundwater, are found in most of the samples. The presence of aragonite and carbonate-hydroxide hydrate minerals argues for interaction of the serpentine deposits with fluids other than seawater.

There are numerous examples of sedimentary serpentinite deposits exposed on land that are very similar to the deposits recovered from the serpentine seamounts drilled on ODP Leg 125. We suggest that Conical Seamount may be a type locality for the study of in situ formation of many of these sedimentary serpentinite bodies. Further, we suggest that both the deposits drilled on Conical Seamount and on Torishima Forearc Seamount demonstrate that serpentinization can continue in situ within the seamounts through interaction of the serpentine deposits with both seawater and subduction-related fluids.
\end{abstract}

\section{INTRODUCTION}

Studies of the formation and composition of serpentine seamounts drilled during Leg 125 on the Mariana and Izu-Bonin forearc regions (Fig. 1) have direct application to interpretation of subaerial exposures of serpentinite in former convergent margin terranes. Deposits of "sedimentary" serpentinite similar to the deposits formed on the flanks of the Mariana serpentine seamounts have been described from numerous locations on land in former convergent margin settings (e.g., Lockwood, 1971, 1972; Phipps, 1984; LaGabrielle et al., 1986) and the mechanism of emplacement of some of these has been compared with that of certain of the Mariana seamounts (Carlson, 1984). Over 50 seamounts exist on the outer half of the Mariana forearc region (Fryer and Fryer, 1987). Dredges from these recovered dominantly serpentinized ultramafic rocks; most also yielded metagabbros, metabasalts, and metasediments (Bloomer, 1982; Bloomer and Hawkins, 1983; Fryer et al., 1987, 1990; Johnson, this volume; Saboda et al., this volume). These rocks represent, in part, forearc mantle materials, possibly entrained in the rising serpentinite, and thus indicate the nature of metamorphic processes occurring both at depth and within the individual edifices.

The best studied of these seamounts are two near a large graben in the outer Mariana forearc region at about $19^{\circ} \mathrm{N}$ (Fryer and Fryer, 1987; Fryer et al., 1987). Serpentinized ultramafic materials, metamorphosed mafic rocks, manganese crusts with adhering pelagic sediments, and some semi-lithified, vitric siltstones were dredged from both seamounts (Fryer and Fryer, 1987; Saboda, 1991). SeaMARC II side-scan sonar images and bathymetry of the two seamounts in this region showed flow features of various types on their flanks (Fryer et al., 1985; Hussong and Fryer, 1985; Fryer and Fryer, 1987).

\footnotetext{
' Fryer, P., Pearce, J. A., Stokking, L. B., et al., 1992. Proc. ODP, Sci. Results, 125: College Station, TX (Ocean Drilling Program).

${ }^{2}$ School of Ocean and Earth Science and Technology, Planetary Geosciences, Department of Geology and Geophysics, University of Hawaii, 2525 Correa Rd., Honolulu, HI 96822, U.S.A.

${ }^{3}$ School of Ocean and Earth Science and Technology, Department of Oceanography, University of Hawaii, 1000 Pope Rd., Honolulu, HI 96822, U.S.A.
}

The northern seamount (informally named Conical Seamount) is a well-defined, roughly circular edifice, with a basal diameter of about $20 \mathrm{~km}$ and relief of $1500 \mathrm{~m}$. It lies at a distance of about $80 \mathrm{~km}$ west from the Mariana Trench axis (Fig. 2). The base of the seamount is readily distinguishable on Sea MARC II side-scanning sonar images (Fig. 3) from the surrounding, relatively flat seafloor. The lower flanks, especially on the southeast side show concentric, longwavelength ridges. Long sinuous flows, indicating low viscosity, show high backscatter (dark regions) on the side-scanning sonar image and mantle all flanks of the seamount. The flows extend for distances of up to $18 \mathrm{~km}$ from the summit. Conical Seamount covers an area of approximately $700 \mathrm{~km}^{2}$. The total area covered by the sinuous flows is approximately $550 \mathrm{~km}^{2}$. These flows were initially interpreted as normal forearc sediments that had been mobilized into debris flows by gravitational instability and by infusion of the sediments with fluids venting from a near-surface serpentinite diapir (Fryer et al., 1985; Fryer and Fryer, 1987). This interpretation suggested that Conical Seamount might represent a large mud volcano.

The eastern $50 \mathrm{~km}$ of the Izu-Bonin forearc region is morphologically, compositionally, and structurally different from the remainder of this forearc region. Within $50 \mathrm{~km}$ of the trench axis, a ridge runs for more than $500 \mathrm{~km}$ along the lowermost, inner wall of the Izu-Bonin Trench, at latitudes north of about $30^{\circ}$ (Honza and Tamaki, 1985). This ridge (Fig. 4) is separated from the outer-arc high by a narrow ( $10 \mathrm{~km}$ wide) sediment trough. A series of seamounts is situated along its eastern and western boundaries. Dredges from two of these seamounts, one at $32^{\circ} \mathrm{N}$ (Saboda et al., 1987; Saboda, 1990) and the other at about $31^{\circ} \mathrm{N}$ (Kobayashi, 1989), recovered serpentinized ultramafic rocks. The seamount at $31^{\circ} \mathrm{N}$, chosen for Site 783 (Fig. 5), was dredged in 1988 at three locations, yielding a wide variety of sedimentary, igneous, and metamorphic rocks (Kobayashi, et al., 1989). Most samples dredged from the two summit locations were serpentinized ultramafic and mafic rocks, showing slickensides and fractures. Some pumice fragments and sedimentary rocks also were retrieved from the summit and constituted the bulk of the rocks recovered from the lower, west flank of the seamount. A very small amount of serpentine mud that had adhered to the surfaces 


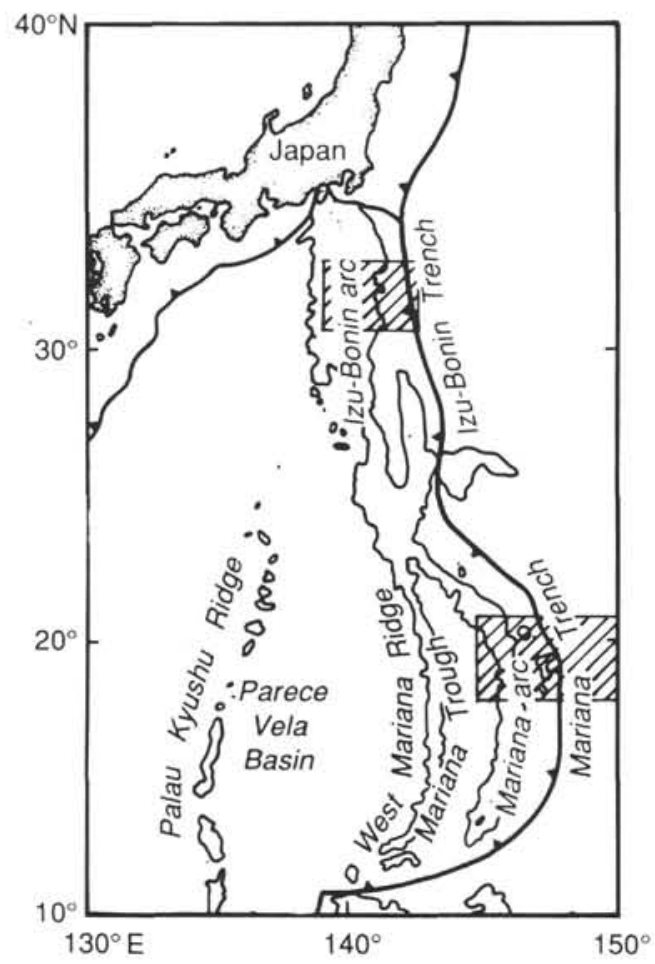

Figure 1. Bathymetry and geologic features in the Philippine Sea region. Basins and ridges are outlined by the $4-\mathrm{km}$ bathymetric contour, except for the Izu-Bonin arc, West Mariana Ridge, and Mariana arc, which are outlined by the $3-\mathrm{km}$ contour. Barbed lines locate subduction zones. Shaded boxes indicate locations of Figures 2 and 4 .

of a few of the metamorphosed rocks was recovered. Fault planes, noted on several multichannel seismic lines (Fig. 4), run both across the seamounts and the inner wall of the trench (Horine et al., 1990), suggesting that the ridge is still tectonically active. By comparison with Conical Seamount, Torishima Forearc Seamount is far more complex. The summit region of this seamount is broken by numerous small fault blocks (Marlow et al., 1990). Thus, it is unlikely that the seamount is currently producing serpentinite flows, however, the seamount may have produced serpentine mud flows earlier in its history.

Both of these serpentine seamounts provide an opportunity to study deep-seated processes of metamorphism and fluid flux through an intraoceanic forearc region. Conical Seamount is a site of active protrusion of serpentine mud flows forming a serpentine mud volcano. Thus, the study of this seamount enables us to examine in situ both the process of protrusion of these flows and the nature of the associated fluid/rock interactions. The primary objective of our study is to determine the mineralogic variability of the serpentine deposits on these seamounts in order to deduce the possible implications for origin of the seamounts. In addition, this study was designed to determine the nature of the secondary minerals formed during interactions between the serpentine deposits and both seawater and other pore fluids within the seamounts. This secondary objective was to provide data necessary for interpretation of the pore fluid data (Mottl, this volume). The study of the secondary mineralogy of the samples proves to be important not only as the basis for interpretation of the pore fluids, but also as an indicator of an alteration process previously unknown in oceanic serpentine samples.

\section{BACKGROUND}

The following summary from the site chapters for Sites 778, 779, 780, 783, and 784 in Fryer, Pearce, Stokking, et al. (1990) presents the lithology and structural interpretations of the pertinent serpentinebearing units recovered, as modified by post-cruise, shore-based efforts. It should be noted that recovery was poor. It is thought that coring preferentially retrieved ultramafic rock clasts enclosed in unconsolidated silt- and clay-sized serpentine.

\section{Conical Seamount}

\section{Hole 778A (Fig. 6)}

Subunit IA (0.0-7.2 mbsf, 125-778A-1R-1, $0 \mathrm{~cm}$, to $-2 \mathrm{R}-1,50 \mathrm{~cm}$, Holocene(?) to upper Pleistocene) primarily consists of clay-and silt-sized serpentine (with sand to pebble-sized clasts of serpentinite). A small amount of vitric siltstone was recovered from the uppermost portion of this subunit. Analysis of smear slides indicates serpentine (65\%), opaques $(10 \%)$, epidote/zoisite $(10 \%)$, aragonite $(10 \%)$, nannofossils $(5 \%)$, and trace amounts of radiolarians and silicoflagellates. Seawater below a few hundred meters in the present-day Pacific is undersaturated with respect to aragonite (Li et al., 1969; Berner and Honjo, 1981), and the aragonite compensation depth is less than $1000 \mathrm{mbsl}$ in the Pacific, usually as shallow as $400 \mathrm{mbsl}$ (Berger, 1970). The delicate, acicular aragonite crystals (up to $3 \mathrm{~mm}$ in length, $0.5 \mathrm{~mm}$ in width) in the clay and serpentine imply in situ, authigenic growth after the serpentine was emplaced. The aragonite needles could not be detrital, as transport would tend to break them.

Subunit IB (7.2-29.8 mbsf, 125-778A-2R-1, $50 \mathrm{~cm}$, to -5R-1, 10 $\mathrm{cm}$, Pleistocene to Pliocene) is possibly primarily drilling breccia of serpentine, but contains several rock clasts. Two of these are fossiliferous and permit age determinations. In a thin section of a pebble (Sample 125-778A-4R-1, 5-6 cm), trace amounts of poorly preserved radiolarians and Neogene planktonic foraminifers (N21N22) were found in a clay matrix. Coarser grains included in the pebble are rock fragments of vesicular volcanics and crystals of olivine. The lowest pebble in this section is a foraminifer-bearing serpentine sandstone of Pleistocene age (N22), composed of serpentine $(65 \%)$, opaques $(12 \%)$, epidote $(10 \%)$, chlorite $(5 \%)$, aragonite $(5 \%)$, foraminifers $(3 \%)$, and a trace amount of nannofossils. It is possible that the unit is reworked either as a primary feature or as a consequence of drilling disturbance.

Unit II (29.8-107.6 mbsf, 125-778A-5R-1, $10 \mathrm{~cm}$, to -13R-CC) is primarily composed of phacoidal and sheared serpentine and intervals of serpentine breccia with a convolute structure. The matrix of the breccia is composed of serpentine $(50 \%-80 \%)$, opaques $(20 \%-$ $5 \%$ ), thulite(?) (25\%-0\%), epidote/zoisite $(30 \%-0 \%)$, chlorite $(15 \%-$ $0 \%)$, talc $(5 \%-0 \%)$, olivine $(5 \%-0 \%)$, and trace to $0 \%$ of albite.

Mineral identification by X-ray diffraction (XRD) analysis was performed on board the ship for five samples obtained from Site 778, both on powder (pow) and oriented pipette (pip) samples. Powder samples were dried, ground manually in an agate mortar, and packed in a sample holder. Pipette samples were prepared from the $<4 \mathrm{~mm}$-fraction which was separated by sedimentation in a $20 \mathrm{~mL}$ beaker. All samples contain serpentine and almost all samples contain brucite. Olivine, epidote/zoisite, and aragonite also are present. Chlorite, goethite, stevensite, and garnierite also are possibly present in the sediments.

Small-scale original layering within Unit II is preserved locally, defined by alternating zones of gravelly serpentine muds of different colors within the abundant convoluted, irregular folds. Foliation, either horizontal or oblique, has developed locally, especially around major shear bands which crosscut the cores. This foliation is emphasized both by alignment of stretched millimeter- to centimeter-sized serpentinized clasts and by discontinuous, sheared laminae. A thin, 
146 $147^{\circ}$

$148^{\circ}$

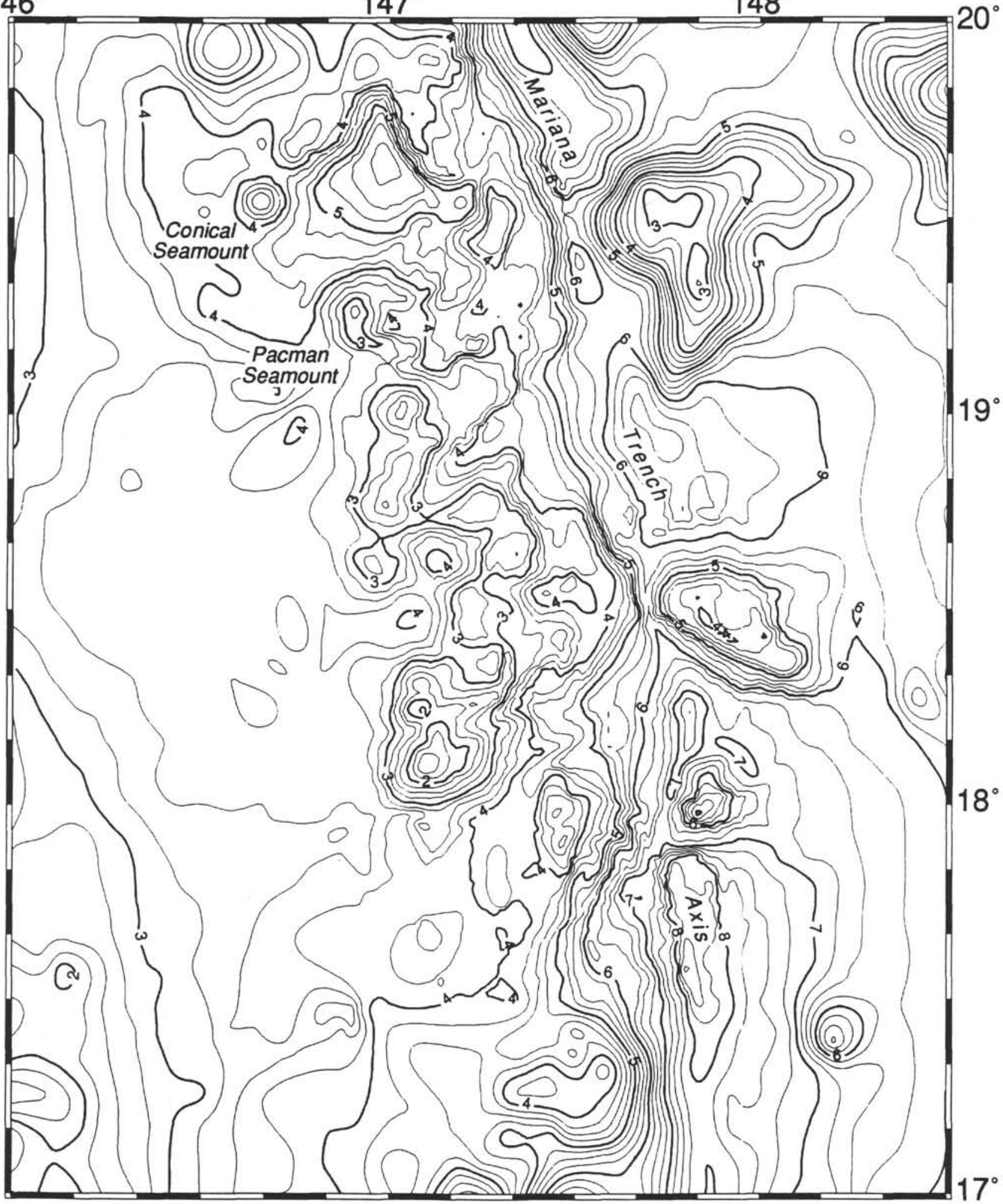

Figure 2. Bathymetry (in kilometers) of the central Mariana arc from SeaMARC II, seismic reflection, and U.S. Navy SASS data (after Fryer and Smoot, 1985) 
A

$146^{\circ} 40^{\prime} \mathrm{E}$

।

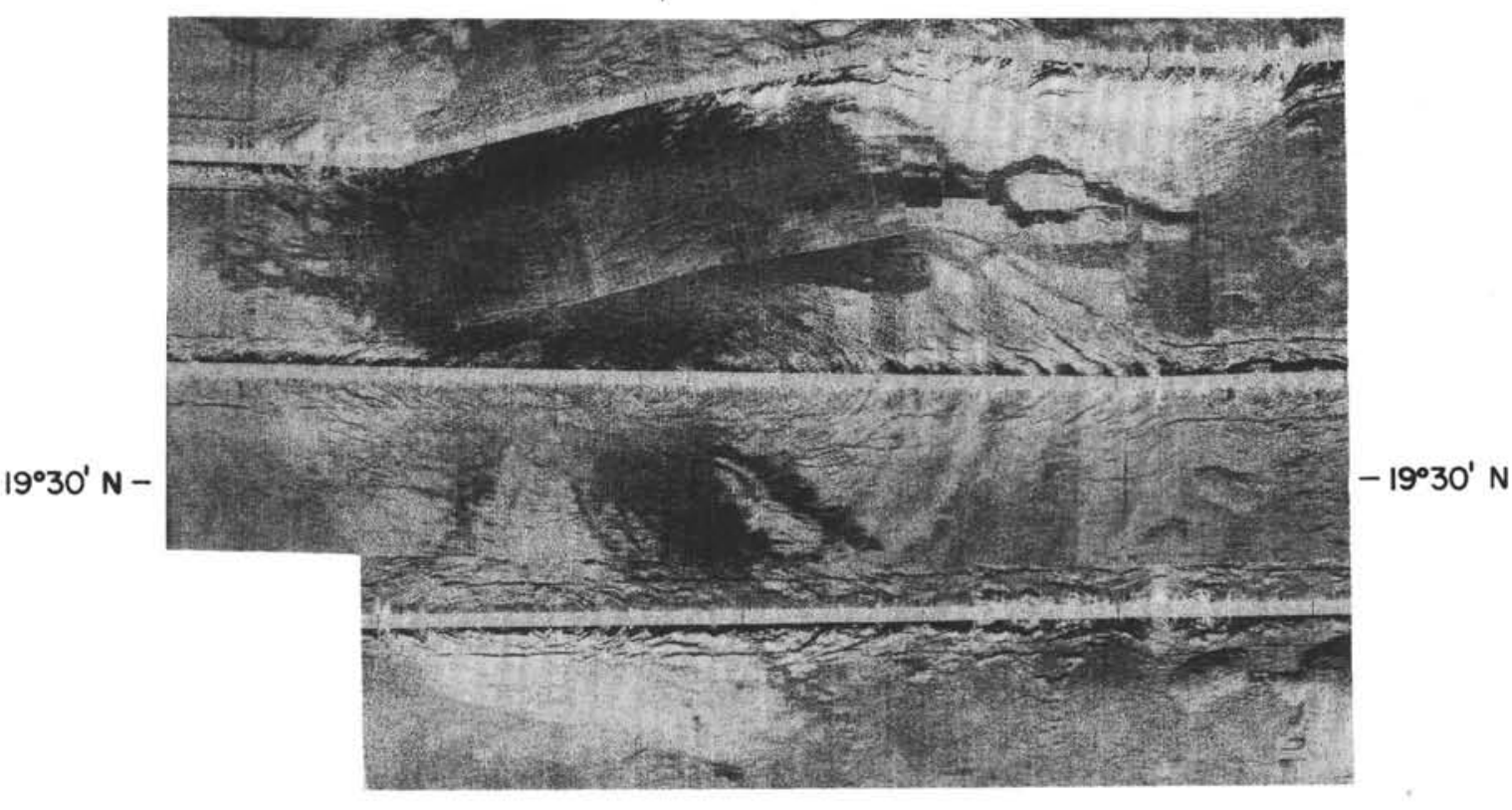

은

$10 \mathrm{KM}$

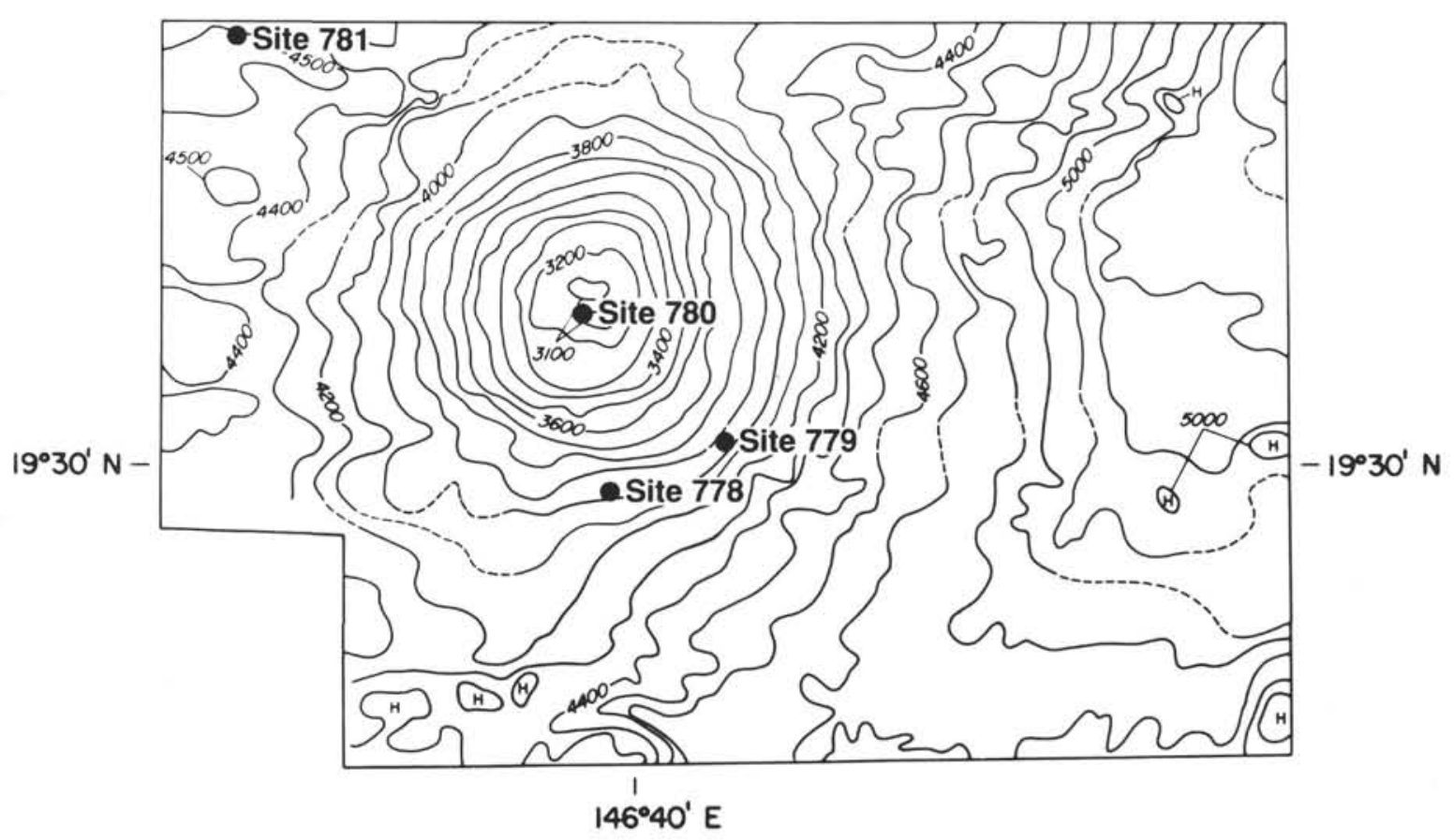

Figure 3. SeaMARC II side-scanning sonar image (dark regions indicate areas of high back-scatter from sonar signals) and bathymetric map of Conical Seamount. Labeled sites are locations of drill holes from which were taken samples for this study. 


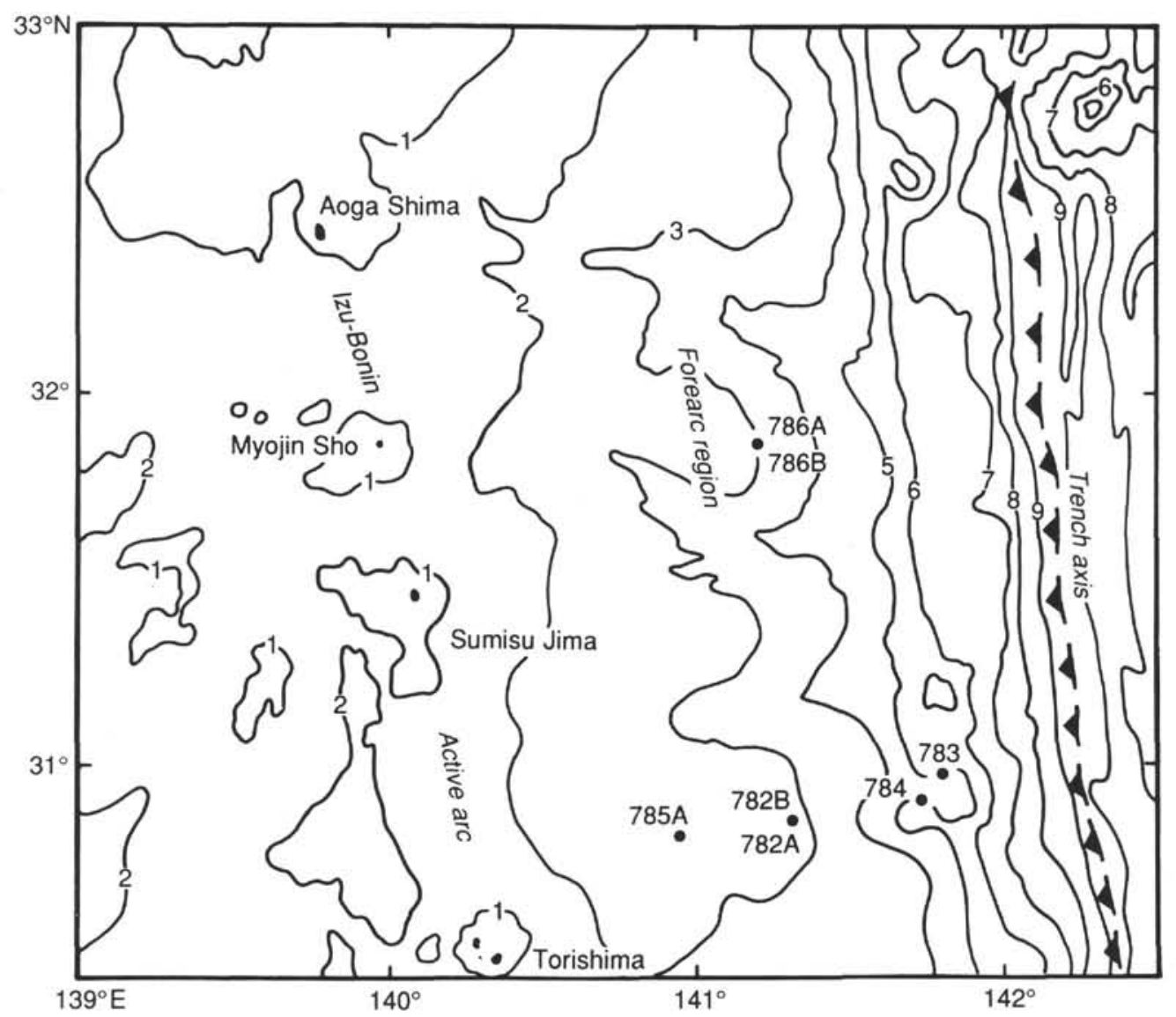

Figure 4. Bathymetric map (in kilometers) of the Izu-Bonin forearc region showing locations of the sites drilled on Legs 125. Sites 783 and 784 are on the north and west flanks (respectively) of Torishima Forearc Seamount (see Fig. 5). These are the sites from which were taken samples for this study.

anastomosing cleavage, similar to scaly-clay cleavages (argille scagliose) has also developed, almost parallel to the foliation. This cleavage is locally enhanced by the development of pale green laminae (chrysotile rich?). Examination of the poorly consolidated matrix using impregnated thin sections suggests that the foliation is well-defined locally by the preferred orientation of the serpentine flakes. Garnet (identified on board the ship as hydrogrossular) crystals locally form long chainlets and clusters that are clearly located within the foliation planes. Epidote-group minerals (mainly? zoisite) are located within the foliation planes, indicating that crystallization is pre- to syn-deformation. Decimeter-size folds may affect the foliation. Tightly folded and sheared serpentine monocrystals were observed in thin-section. Anastomosing foliation planes and curving foliation planes around clasts define shear lenses (phacoids) on all scales. The presence of horizontal to gently-dipping shear zonesindicates that horizontal displacement took place on the flank of the seamount. Such displacements imply gravitational instability of the upper part of the seamount.

\section{Hole 779A (Fig. 7)}

Unit I (Hole 779A: 0-10.6 mbsf, 125-779A-1R-1, $0 \mathrm{~cm}$, to -2R-5, $68 \mathrm{~cm}$; Holocene? to lower Pleistocene) primarily consists of serpentine clay- and silt-sized serpentine, with sand- to pebble-sized clasts of serpentinite and other lithic fragments. Of the strata recovered at this site, only Unit I contains sediment with well-preserved biogenic components. The silt- and clay-sized serpentine contains authigenic aragonite needles. The smear slides range from $60 \%-75 \%$ serpentine, $7 \%-20 \%$ opaques,
$0 \%-15 \%$ aragonite, $5 \%-10 \%$ epidote/zoisite, $0 \%-5 \%$ clay, $0 \%$ to a trace of chlorite, and $0 \%$ to a trace of garnet. Sandy silt- and sandy clay-sized serpentine from Cores 125-779B-1R, and 125-779A-2R was deposited during or after the early Pleistocene on the basis of nannofossils found in Sections 125-779B-1R-CC, and 125-779A-2R5. On the basis of similar lithologies and biostratigraphic criteria, this unit correlates with Unit I at Site 778.

Unit II (10.6-303.0 mbsf, 125-779A-3R, CC, to -35R-1, $133 \mathrm{~cm}$; lower Pleistocene? to lower Pliocene?) contains clasts of various igneous and metamorphic lithologies (Johnson, Maekawa, et al., and Saboda et al., this volume) in a clay- and silt-sized serpentine matrix. The matrix is composed of $73 \%-90 \%$ serpentine, $5 \%-10 \%$ amphibole(?), $5 \%-10 \%$ opaques, $0 \%-15 \%$ epidote/zoisite, $0 \%-25 \%$ thulite(?), $0 \%-5 \%$ chlorite, with trace amounts of garnet, plagioclase(?), and olivine. The unit is divided into two subunits because sedimentary strata with primary sedimentary structures are intercalated in the lower portion of the unit. The division of the subunits may be artificial because of poor core recovery (typically less than $35 \%$ ).

Subunit IIA (10.6-216.2 mbsf, 125-779A-3R, CC, to -26R, $150 \mathrm{~cm}$; lower Pleistocene?) is, for the most part, highly deformed by drilling, although locally primary structural features are observed. In Cores 125-779A-7R, -9R, and -10R, the matrix appears to be sheared; in Cores $125-779 A-13 R,-15 R$, and $-18 R$, the matrix has a phacoidal, sheared texture. The sedimentary strata in Subunit IIA contain carbonate grains, kerogen, and filamentous opaque debris interpreted aboard ship as remnants of bacteria (Cores 125-779A-27R, -28R, and -32R).

Subunit IIB (216.2-303.0 mbsf, 125-779A-27R-1, $0 \mathrm{~cm}$, to -35R$1,133 \mathrm{~cm}$; lower Pliocene?) contains faint horizontal bedding and 


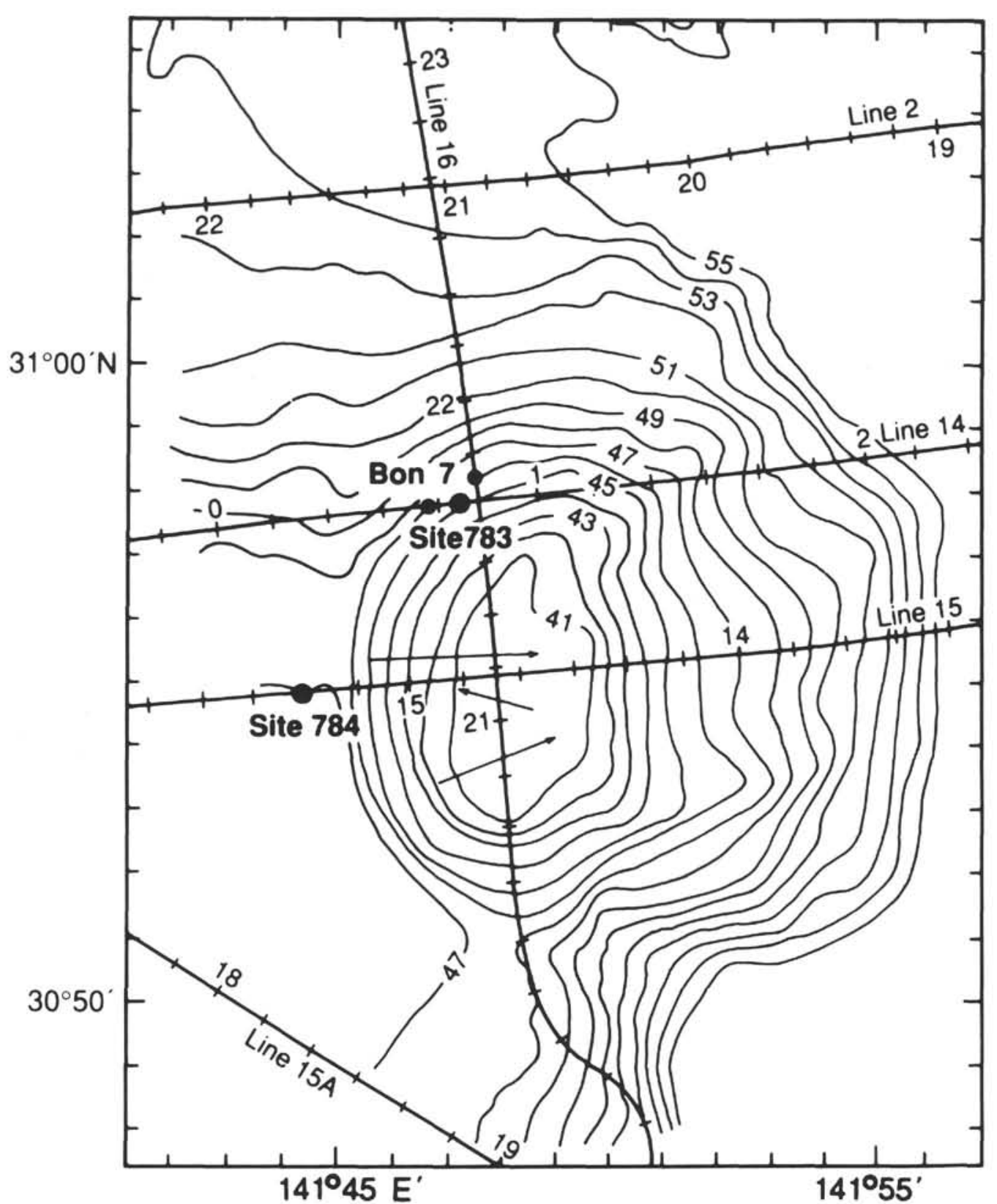

Figure 5. Bathymetry (in hundreds of meters) of Torishima Forearc Seamount showing locations of Sites 783 and 784 and the locations of dredges made on the summit region of the seamount (arrows).

sedimentary structures in sediments intercalated with clay- and siltsized serpentine, suggesting a primary sedimentary origin for the pelagic sediment. Clay layers with filamentous organics are horizontal and separate serpentine layers that have deformational structures. These clay layers may represent periods of exposure on the seafloor, or hiatuses between episodes of deformation. If the filamentous organics represent bacteria that grew at or near the sediment/water interface, then these horizontal beds separate different events of serpentine deposition. Sparse nannofossils of late Miocene/early Pliocene age, including reworked Oligocene nannofossils, have been identified in Sample 125-779A-27R, $60 \mathrm{~cm}$. The base of Unit II is therefore interpreted as having been deposited during or prior to the early Pliocene. An early Pleistocene age determined from sediments in the core catcher of Core 125-779A-2R limits the youngest time of deposition of Unit II.
Unit III (303.0-317.2 mbsf, 125-779A-36R-1, $0 \mathrm{~cm}$, to 125-779A$37 \mathrm{R}, \mathrm{CC}$ ) is composed of clay- and silt-sized serpentinite microbreccia with convolute structures. The matrix of the breccia is composed of serpentine $(70 \%-90 \%)$, opaques $(4 \%-10 \%)$, chlorite $(0 \%-20 \%)$, epidote/zoisite $(0 \%-14 \%)$, amphibole $(0 \%-5 \%)$, micrite (trace to $5 \%$ ), and $0 \%$ to trace amounts of garnet, dolomite, and organic debris. These convolute structures possibly result from a combination of drilling disturbance and primary deformational textures produced by tectonic or gravitational flow processes.

Some XRD analyses were performed on the $<4 \mathrm{~m}$ fraction of five selected serpentine mud samples from Hole 779B. Although some smectite was expected, none was observed. The sample closest to the sediment surface contained traces of an expandable chlorite. No other expandable clays were observed. The $<4-\mathrm{m}$ fraction of the silty clay-sized serpentine is composed entirely of serpentine, probably of 


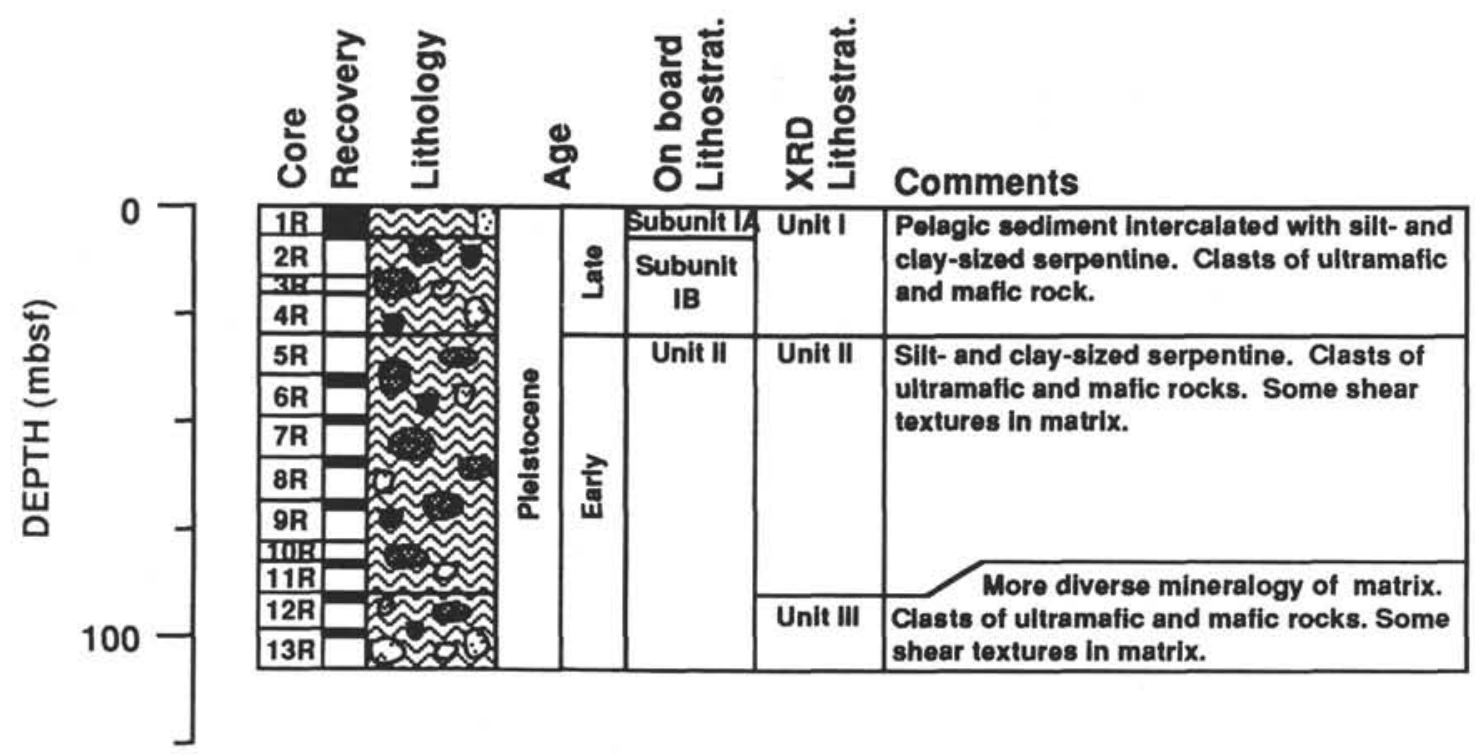

Legend

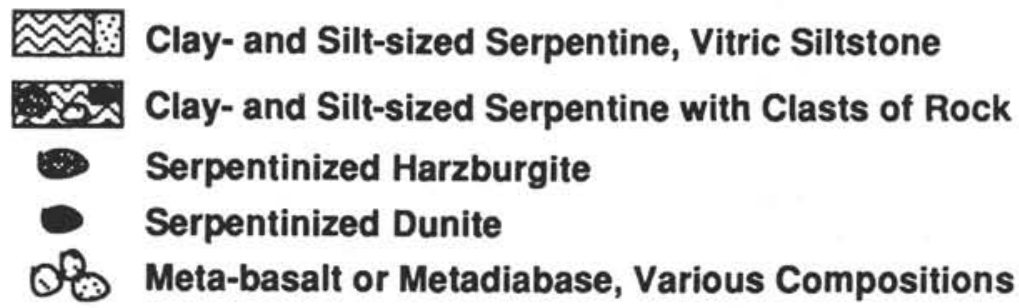

Figure 6. Lithostratigraphic summary of Hole 778A (compiled from descriptions made aboard the ship and from this study).

all three phases (chrysotile, antigorite, and lizardite). In some samples minor amounts of talc are present.

At Site 779, structures related to tectonic processes are found both in hard rocks (serpentinized peridotites, metagabbros, and metabasalts) and in soft sediments. In the soft sediments recovered between the serpentinized peridotite blocks in Lithologic Unit II, a non-penetrative deformation is defined locally by plastic folds. A pervasive, repeated cleavage is also locally present. Anastomosing cleavage planes developing around soft or hard serpentinitic elements define small lenses, called phacoids. Primary deformation structures of the sedimentary serpentinites between the entrained metamorphic blocks can be interpreted as the result of differential movements between the blocks. This deformation may have coincided either with the uprise of the serpentine muds within the seamount or with the lateral flowing of the unconsolidated muds on the flanks of the seamount. The presence of fossiliferous sediments within Lithologic Subunit IIB, suggesting that Lithologic Subunit IIA was emplaced laterally on the seafloor (gravity nappe), favors lateral flow on the flanks of the seamount. Deformation within the sediments of Lithologic Unit III could also be consistent with gentle flowage under gravitational forces.

\section{Holes 780A, B, C, and D (Fig. 8)}

Unit I (0.0-3.5 mbsf, $125-780 \mathrm{~A}-1 \mathrm{H}-1,0 \mathrm{~cm}$, to $-1 \mathrm{H}-1, \mathrm{CC}$; 0.0-18.2 mbsf, $125-780 \mathrm{~B}-1 \mathrm{R}-1,0 \mathrm{~cm}$, to $-2 \mathrm{R}, \mathrm{CC}$; $0.0-14.0 \mathrm{mbsf}$, $125-780 \mathrm{C}-1 \mathrm{R}-1,0 \mathrm{~cm}$, to $-2 \mathrm{R}, \mathrm{CC} ; 0.0-15.4 \mathrm{mbsf}$, and $125-780 \mathrm{D}-$ $1 \mathrm{X}-1,0 \mathrm{~cm}$, to $-3 \mathrm{X}, \mathrm{CC}$ ) is primarily a multicolored sand-, silt-, and clay-sized serpentine, with sand- to pebble-sized clasts of serpentinite and other lithic types. No obvious structures of primary sedimentary origin are present, although Unit I contains some sediments with an obvious biogenic and detrital component. There are foraminiferbearing serpentine silts and clays that contain serpentine $(68 \%-76 \%)$, opaque minerals $(5 \%-10 \%)$, aragonite $(5 \%-6 \%)$, foraminifers $(10 \%)$, nannofossils $(1 \%-2 \%)$, spicules $(0 \%-3 \%)$, silicoflagellates $(1 \%-2 \%)$, diatoms $(1 \%)$, and radiolarians $(0 \%-1 \%)$, as well as serpentine clay that contains clay $(20 \%)$, serpentine $(55 \%)$, chlorite (trace), opaque minerals (20\%), and epidote/zoisite (5\%). Where the opaque minerals are abundant in smear slides, they are present as a filamentous mat that may be a remnant of a bacterial mat. Intercalations of these sediments containing pelagic detritus indicate periods of multiple exposure of serpentine at the seafloor. A Holocene(?)middle Pleistocene(?) age range is given for this unit. Sediments in all remaining core catchers from beneath the above-listed samples from Unit I are barren. Thus, the unit is at least middle Pleistocene in age and quite likely older. Most of the serpentine matrix contains authigenic aragonite needles.

On the basis of similar lithologies and biostratigraphic criteria, we have assumed that this unit correlates with Unit I at Sites 778 and 779.

Unit II (14.0-163.5 mbsf, 125-780C-3R-1, $0 \mathrm{~cm}$, to -18R, CC; 15.4-32.4 mbsf, $125-780 \mathrm{D}-4 \mathrm{X}-1,0 \mathrm{~cm}$, to $-7 \mathrm{X}, \mathrm{CC}$ ) is serpentinized harzburgite and serpentinized dunite in a clay- and silt-sized serpentine matrix that is highly deformed by drilling. Smear slide analysis shows serpentine $(70 \%-99 \%)$, opaque minerals $(1 \%-15 \%)$, clay $(0 \%-10 \%)$, epidote/zoisite $(0 \%-5 \%)$, thulite(?) (0\%-trace), chlorite $(0 \%-5 \%)$, with up to $2 \%$ micrite and garnet.

The serpentine matrix recovered from Site 780 lacks the sheared foliation fabrics characteristic of Sites 778 and 779 . Detrital textures 


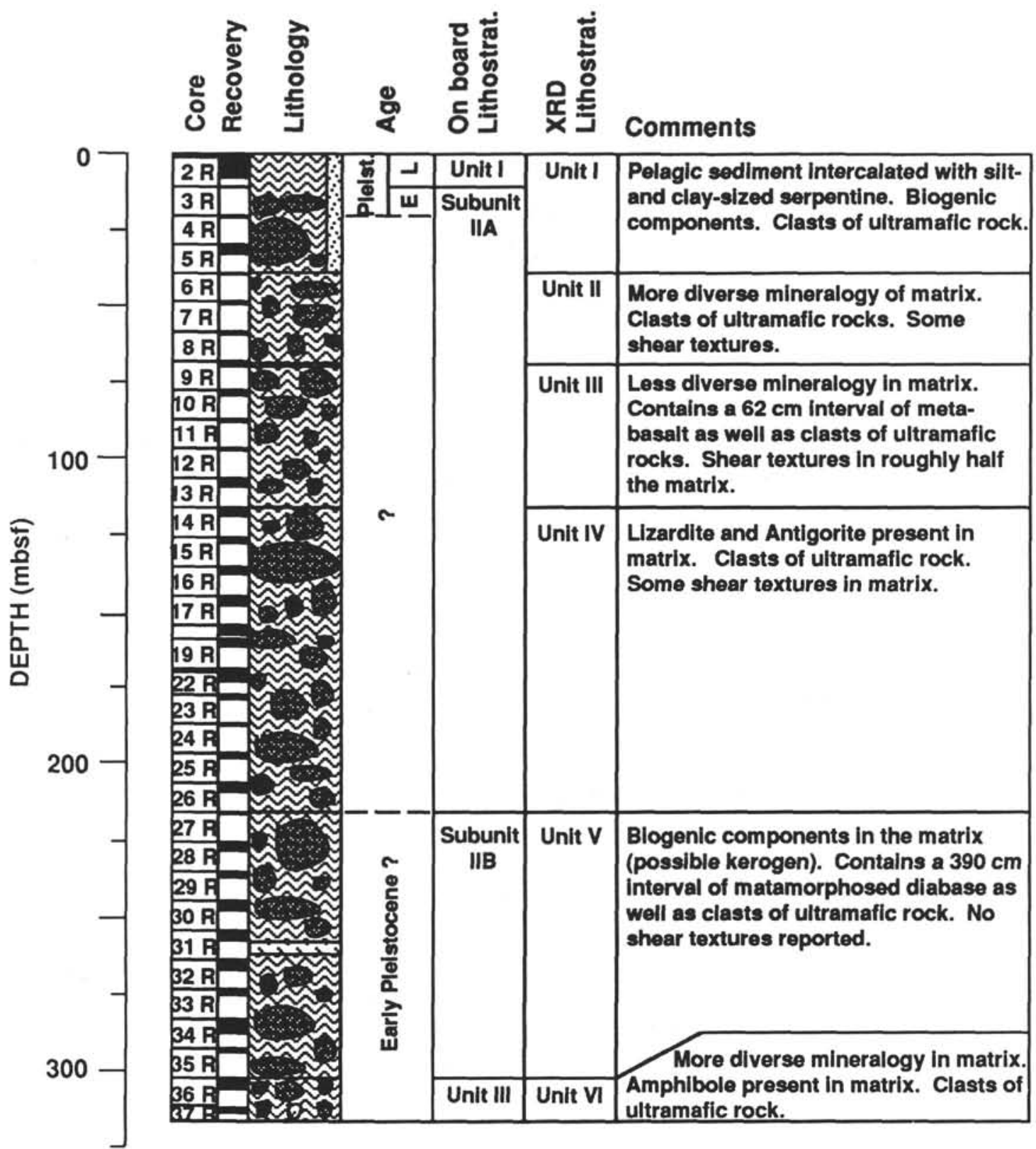

\section{Legend}

Clay- and Silt-sized Serpentine, Vitric Siltstone
Serpentinized Harzburgite
Serpentinized Dunite
Meta-basalt or Metadiabase, Various Compositions

Figure 7. Lithostratigraphic summary of Hole 779A (compiled from descriptions made aboard the ship and from this study). 


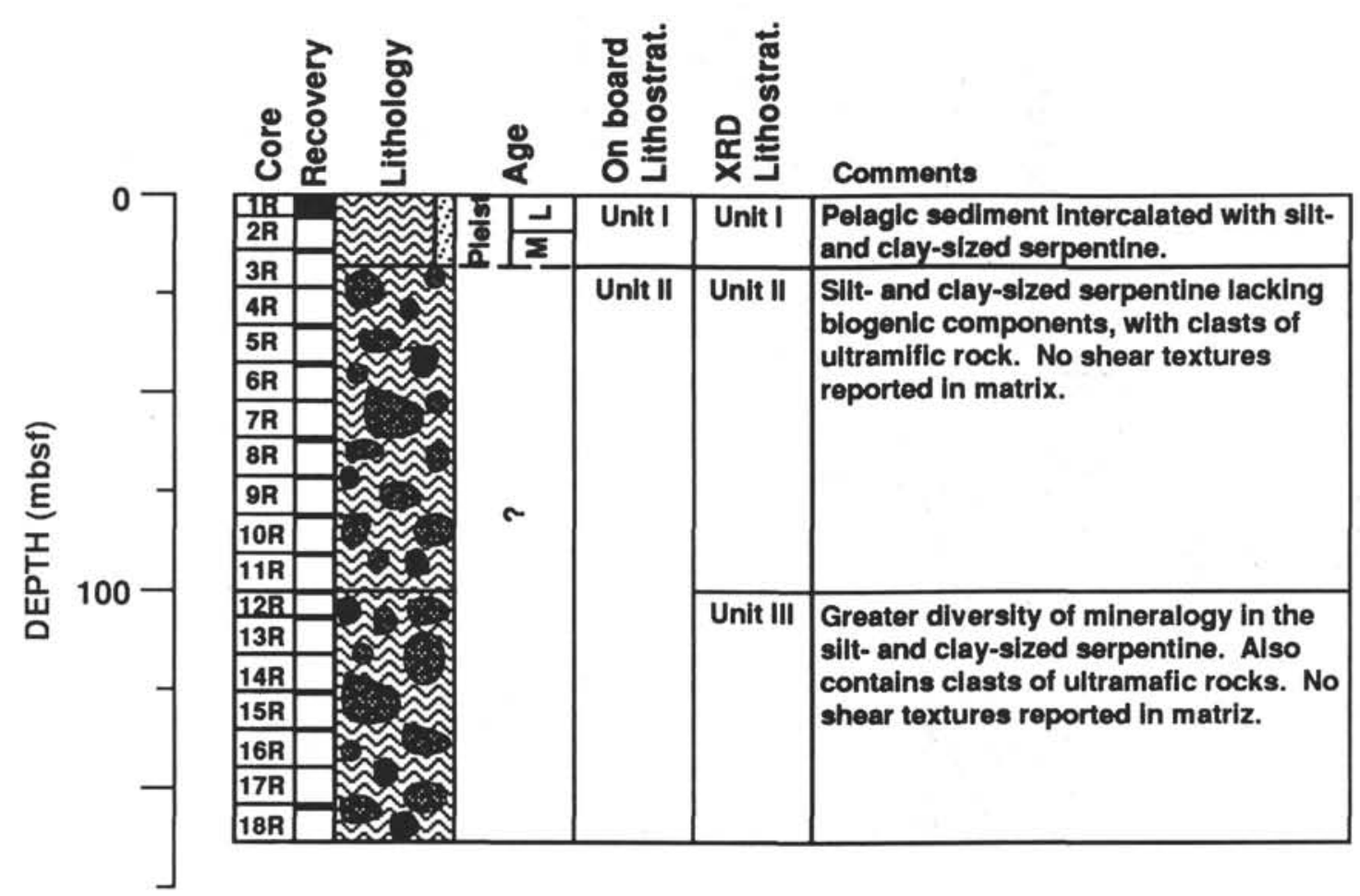

Legend

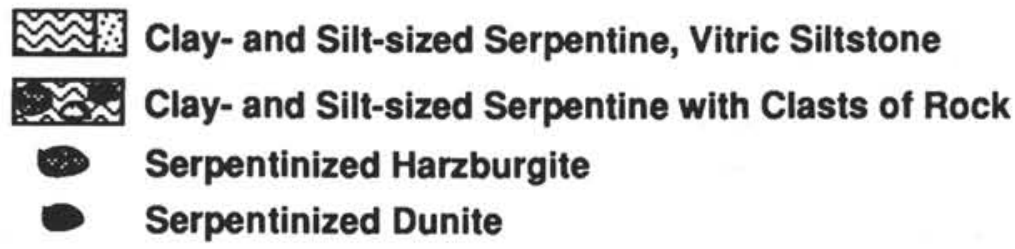

Figure 8. Lithostratigraphic summary of Hole $780 \mathrm{C}$ (compiled from descriptions made aboard the ship and from this study).

(clasts scattered in matrix and subhorizontal lamination) are common in the upper parts of the cores. Matrix recovery was generally poor in the lower parts of the holes, but the approximately $3 \mathrm{~m}$ recovered from a depth of $30 \mathrm{~m}$ at the bottom of Hole 780D shows clast-in-matrix textures, lacking shear foliation, and exhibiting faint subhorizontal boundaries between muds of lightly different color. These undeformed fabrics may be primary textures.

Tests of the stress-strain behavior of serpentinite muds from Hole 780D using a Wykeham-Farrance torsion-vane (torvane) apparatus reveal that the serpentinite muds are highly nonideal plastic materials having ultimate strengths that range from 1.3 to $38 \mathrm{kPa}$ and that average $11.6 \mathrm{kPa}$ (Fig. 5). For comparison, more "normal" oceanic muds recovered from Site 781 were somewhat stronger, having ultimate strengths that range from 8.1 to $116.1 \mathrm{kPa}$. In only two cases did the samples of serpentine muds from Site 780 actually fail. Most serpentinite muds continued to deform at a constant rate at maximum (ultimate) strength. Although no direct determinations of yield strength were performed, our observations of the behavior of these materials suggest that their yield strengths are vanishingly low.

These rheologic measurements suggest three important conclusions about the mechanics of formation of Conical Seamount (Phipps and Ballotti, this volume). First, modeling based on the ultimate strengths of the matrix suggests that it might carry blocks of serpentinized peridotite (density approximately $2.6-2.7 \mathrm{~g} / \mathrm{cm}^{3}$ ) as large as $20 \mathrm{~m}$ upward against the force of gravity. Secondly, the very low yield strengths of the matrix muds suggest that unless the mud continues to well upward from within the conduit of the seamount, any entrained blocks will fall back downward into the conduit. Thirdly, the low strengths measured in the muds are consistent with the interpretation that the seamount is rheologically more like a mud volcano than a salt diapir (salt has an ultimate strength of approximately $10^{4}-10^{5} \mathrm{kPa}$ ). This in turn supports the interpretation that the serpentinite feeder may be relatively narrow with respect to the width of the edifice (Fryer et al., 1990).

\section{Torishima Forearc Seamount}

\section{Hole 783A (Fig. 9)}

Unit I (0-120.0 mbsf, 125-783-1R-1, $0 \mathrm{~cm}$, to $-14 \mathrm{R}-1,12 \mathrm{~cm})$ contains no serpentine, except in the few centimeters immediately overlying the contact with Unit II. Therefore Unit I is not described in detail here. The contact between Lithologic Unit I and Lithologic Unit II (120.0-158.6 mbsf, 125-783A-14R-1, $12 \mathrm{~cm}$, to $-18 \mathrm{R}-1$, $147 \mathrm{~cm}$ ) was not recovered. The interval immediately overlying Unit II that was recovered is a serpentine-bearing, feldspar- and glass-rich silty clay underlain by a $1-\mathrm{cm}$ interval of volcanic ash. A $4-\mathrm{cm}$ void in the core below the ash is followed by a 2-cm diameter clast of serpentinized ultramafic rock. 


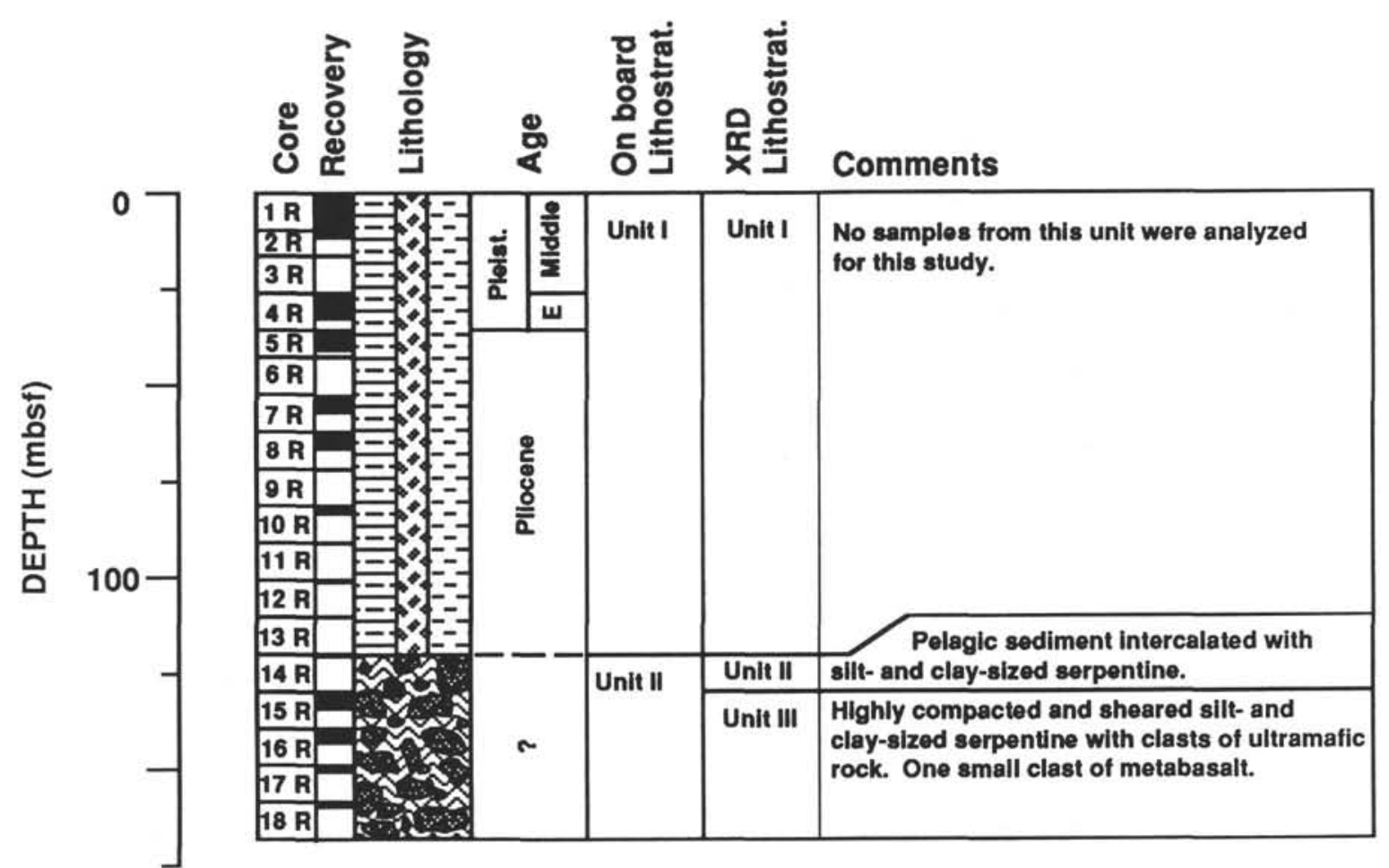

\section{Legend}

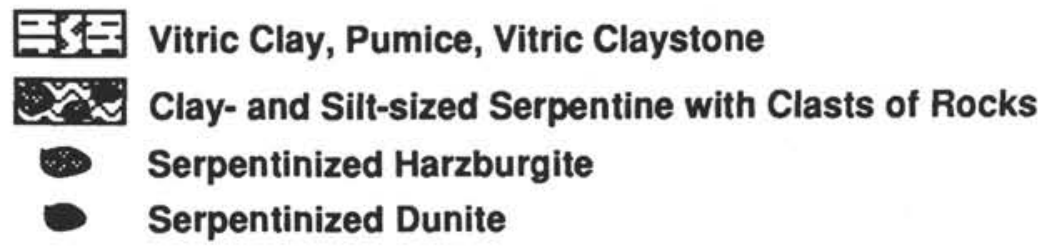

Figure 9. Lithostratigraphic summary of Hole 783A (compiled from descriptions made aboard the ship and from this study).

Lithologic Unit II, which begins with the clast, is composed of phacoidal sheared serpentine that displays convolute bedding and blocks of serpentinized harzburgite. In Core 125-783A-18R the composition is primarily blocks of serpentinized harzburgite with some matrix of phacoidal sheared serpentine. No fossils or obvious detrital components were found in this unit. The age of these strata is unknown. In the absence of evidence for faulting, its likely that this unit is in stratigraphic continuity with Unit I, in which case Unit II is probably at least lower Pliocene (the oldest diatom biostratigraphic age in the overlying Unit I).

The clay- and silt-sized serpentine matrix of Unit II exhibits anastomosing shear foliation that is always parallel to the layering and is defined by deformed color banding, by the long axes of phacoidal serpentine fragments, and by variations in clast size and concentration. Phacoids within the matrix typically exhibit pinchand-swell texture (boudinage) along their long axes, and commonly are cut by serpentine veins and/or microfaults at high to moderate angles with respect to their long axes. These microfaults show a normal sense of movement with respect to the long axes of the phacoids. This texture, together with the boudinage and veining, indicates that the phacoidal matrix has undergone major extension (pure shear) parallel to the layering, foliation, and the direction of alignment of the phacoids. This extension was both brittle and ductile. Cross-fiber serpentine veins (chrysotile [Saboda et al., this volume]), up to $3 \mathrm{~mm}$ across and clearly growing in the serpentine, suggest that serpentinization is continuing in the matrix.
Rheologic properties of the clay- and silt-sized serpentine were studied using a Wykeham-Farrance torsion-vane apparatus as for Site 780 samples (described above). The sheared, phacoidal serpentine is quite weak, has failure strengths that range between 7.3 and 51 $\mathrm{kPa}$, and average $23 \mathrm{kPa}$ (Fig. 5). The mode of failure of the serpentine of Site 783 was quite different from that of serpentine of Site 780. At low strains, the stress-strain curves for the Site 783 serpentine were much more linear, and the strain appeared to be more elastic than that for Site 780 serpentine. Moreover, the serpentine failed in a brittle manner, by cracking, rather than by yielding plastically at an ultimate strength. These rheological properties indicate a greater dewatering and compaction of serpentine deposits than those from the summit of Conical Seamount.

The serpentine at Site 783 is blanketed by virtually serpentine-free sediment that is at least as old as early Pliocene. Thus, the stratigraphy, sedimentology, paleontology, and rheology of the materials recovered from Site 783 are all consistent with a scenario in which serpentinite debris-flow processes, possibly similar to those observed at Conical Seamount were once active, but have since ceased, allowing the serpentine to be blanketed with pelagic and volcanogenic sediment. Serpentinization and dewatering are still active.

\section{Hole 784A (Fig. 10)}

Subunit IC (302.7-321.1 mbsf; 125-784A-33R-2, $120 \mathrm{~cm}$, to $-35 R-2,34 \mathrm{~cm}$ ) is composed of intercalated claystone and clay- and 


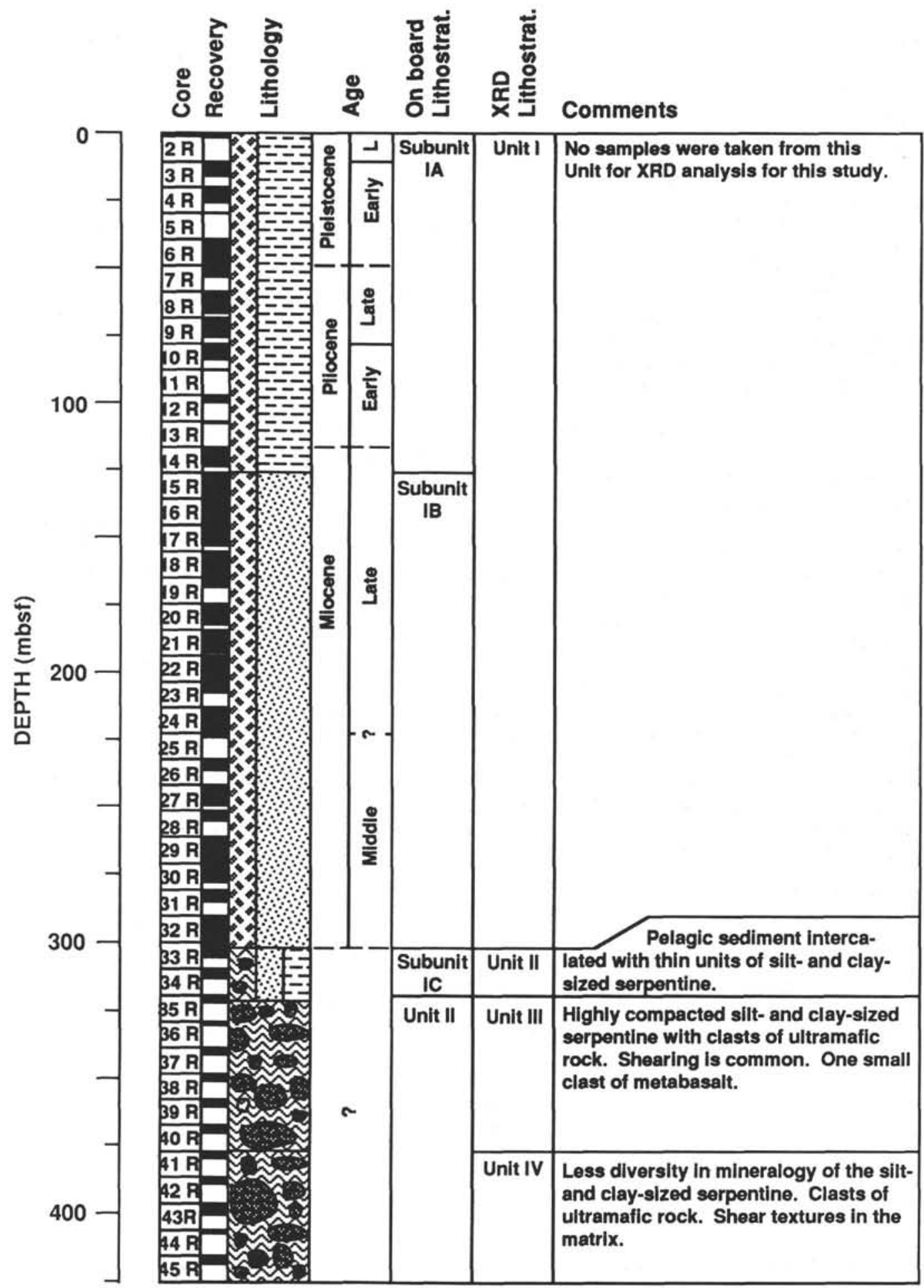

Legend

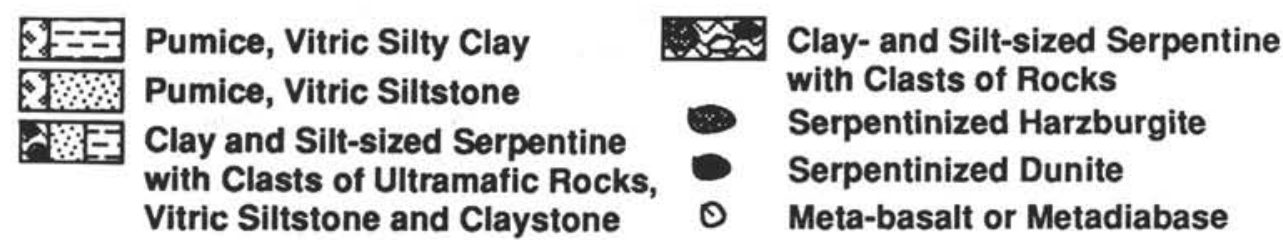

Figure 10. Lithostratigraphic summary of Hole 784A (compiled from descriptions made aboard the ship and from this study). 
silt-sized serpentine. The serpentine is typically interlayered with the claystone with the exception of a different structure in the serpentine interval from 91 to $136 \mathrm{~cm}$ in Section 125-784A-35R-1. From 91 to $121 \mathrm{~cm}$, there is a serpentine breccia with a faint phacoidal texture. Subunit IC contains no biogenic material and thus remains undated.

Unit II (321.1-425.3 mbsf; 125-784A-35R-2, $34 \mathrm{~cm}$, to -45R, CC) contacts Unit I at an abrupt change to sheared, phacoidal, serpentine microbreccia with vertical, convolute bedding lacking any intercalated sediment. Blocks of serpentinized harzburgite with a matrix of phacoidal, sheared, serpentine microbreccia appear in Core 125$784 \mathrm{~A}-36 \mathrm{R}$ and continue throughout the remainder of the unit. In the lowermost portion of this unit, an apatite-bearing, silt-sized serpentine (Core 125-784A-44R) and a chlorite-bearing, silt-sized serpentine (Core 125-784A-45R) are associated with the phacoidal, sheared, silt-sized serpentine microbreccia and the blocks of harzburgite. The presence of Pleistocene nannofossils and siderite (rhodochrosite?) in siltstone indicate downhole contamination at the tops of Cores 125784A-36R, -37R, -38R, -39R, and -43R. No fossils were found within the phacoidal, sheared, serpentine microbreccia. Thus, the age of these strata is unknown. Lithologic Unit II probably is either locally derived from the adjacent topographic high or represents the underlying "acoustic basement" at this site. This unit correlates with lithologic Unit II at Site 783 on the northern flank of the seamount.

In Subunit IC the interlayering of poorly sorted clastic serpentine sediments containing coarse angular fragments with much bettersorted, finer-grained, volcanogenic/pelagic sediments provides good evidence for interfingering between locally derived serpentine debris flows and pelagic sediment. In Unit II phacoidal, sheared serpentine is abundant, most of the phacoids are sheared, soft clasts. Some have asymmetrical shapes, suggesting deformation by simple shear. Rheological studies performed using the Wykeham-Farrance torsionvane apparatus showed the average strength of the serpentine at Site 784 to be $54.5 \mathrm{kPa}$ higher than the maximum strengths of the serpentine at other sites (Fig. 5). The greater strength of the Site 784 serpentine is attributed to the greater degree of desiccation and lithification of the units as a consequence of their deeper burial and greater age by comparison with comparable units from other sites.

\section{SHORE-BASED MINERALOGICAL STUDIES}

\section{Samples and Methods}

Samples chosen for this study from Sites $778,779,780,783$, and 784 were taken from the squeeze cakes of whole-round cores used for shipboard pore-water analysis. The objectives of this study are (1) to characterize the major minerals present in the serpentine muds, (2) to identify lithologic/mineralogic units in the holes, and (3) to provide the mineralogical companion to the studies of pore-water geochemistry of these samples (Mottl, this volume; and Haggerty and Chaudhuri, this volume). The X-ray diffraction (XRD) analysis of the samples provides a more detailed description of the mineralogical content of the serpentine and highlights the discovery of formation in situ of several minerals in the rare hydroxide carbonate hydrate group.

Whole-round sections of core 5- to $15-\mathrm{cm}$ long were squeezed on board the ship at pressures up to $40,000 \mathrm{psi}$ in a stainless steel squeezer (Manheim and Sayles, 1974), using a Carver hydraulic press and squeezed at pressures of up to 40,000 psi. The squeeze cakes were disaggregated by hand, using steel picks. Pebbles (greater than $3 \mathrm{~mm}$ ) were separated from the bulk sample. Most pebbles were of ultramafic rocks. Also separated were subsamples of visually distinct mineralogy. The bulk samples and the subsamples were air-dried and then powdered by grinding with an agate mortar and pestle. Samples had a tendency to form matted aggregates. Powders from the bulk samples were homogenized and mounted in aluminum planchettes and certain of the low volume subsamples were mounted as smear slides on glass plates for XRD analyses.

The samples were analyzed at the University of Hawaii, Department of Oceanography, using a Scintag Pad V X-ray diffractometer integrated with a Data General data collection system that is interfaced with a Macintosh SE computer. The XRD unit utilizes a solid state $\mathrm{Ge}$ detector and a $\mathrm{Cu} \mathrm{K}$-alpha radiation source. Samples were scanned continuously from $2^{\circ}$ to $70^{\circ} 2 \theta$ at a rate of $1^{\circ} 2 \theta / \mathrm{min}$. Tube current was at 40 milliamps and voltage at $45 \mathrm{kV}$. Crystal slits and settings were used.

Criteria for identification of minerals were based on the presence of peaks in the XRD spectra that are characteristic of diagnostic $\mathrm{d}$-spacing. The presence or absence of minerals in the samples was defined as follows: (1) a given mineral was deemed "definitely present" if generally three or more of the largest peaks were present (large solid circles in Table 1); (2) a given mineral was deemed "probably present" if generally one or two of the largest peaks were present in the pattern (large open circles with slash lines); (3) a given mineral was deemed "possibly present" if one or two of the largest peaks were present but ambiguous, for instance, masked by peaks from more abundant minerals (small open circles); (4) a given mineral was deemed "probably absent" if there was little evidence of the largest peaks (absent from Table 1); and (5) a given mineral was deemed "definitely absent" if there was no evidence for even the largest peaks (absent from Table 1). The level of sensitivity of the method precludes detection of nonserpentine minerals present in quantities less than about $10 \%$ and serpentine minerals in quantities less than about $15 \%$. Therefore, minerals deemed definitely absent actually may be present in quantities less than those detectable by this method.

Serpentine is the most abundant mineral in the samples. Thus, the signal from the serpentine phases is so intense that it obscures that from most other minerals. In order to attempt to identify the serpentine phases present the patterns of the bulk samples were compared with data from the mineral powder diffraction file (JCPDS, 1980) and from samples of antigorite, chrysotile, and lizardite supplied by R. G. Coleman and analyzed for this study.

Criteria used for the identification of serpentine and for distinguishing between serpentine phases is given in Appendix A. Diagnostic peaks used for identification of other mineral and additional identification criteria are given in Appendix B.

\section{RESULTS}

\section{Hole 778A}

A summary of the results of the shore-based XRD analysis of the clay- and silt-sized serpentine matrix from Hole 778 A is shown in Table 1. In all of the samples from this hole, the serpentine phase is dominantly chrysotile. Accessory minerals commonly found with serpentine, brucite, chlorite (a Cr-bearing phase), talc, and magnetite and chromite also are present. Clays are present in the sample, although we were not able to distinguish the species. Hectorite $\left(\mathrm{Na}_{\mathrm{x}}(\mathrm{Mg}, \mathrm{Li}) \mathrm{Si}_{4} \mathrm{O}_{10}(\mathrm{OH}, \mathrm{F})_{2}\right)$ may be present in nearly all of the samples we analyzed, however all of its major peaks are shared with chrysotile. A detailed analysis of the clay mineralogy of the samples will be undertaken at a later date. The garnets present are Ca-rich (probably andradite $\mathrm{Ca}_{3} \mathrm{Fe}_{2}\left(\mathrm{SiO}_{4}\right)_{3}$ or goldmanite $\left(\mathrm{Ca}_{3}(\mathrm{~V}, \mathrm{Fe}, \mathrm{Al})_{2}\left(\mathrm{SiO}_{4}\right)_{3}\right)$.

In addition to minerals commonly associated with serpentine, the samples contain members of the sjogrenite mineral group. This group of minerals is comprised nearly exclusively of carbonate-hydroxide hydrates. These minerals are rare, but are found in association with serpentine in several localities, as described below. The principal species identified in our samples include coalingite $\left(\mathrm{Mg}_{10} \mathrm{Fe}_{2}\left(\mathrm{CO}_{3}\right)(\mathrm{OH})_{24}\right.$ $\left.2 \mathrm{H}_{2} \mathrm{O}\right)$; brugnatellite $\left(\mathrm{Mg}_{6} \mathrm{FeCO}_{3}(\mathrm{OH})_{13} 4 \mathrm{H}_{2} \mathrm{O}\right)$; reevesite $\left(\mathrm{Ni}_{6} \mathrm{Fe}_{2}\left(\mathrm{CO}_{3}\right)\right.$ $\left.(\mathrm{OH})_{16} 4 \mathrm{H}_{2} \mathrm{O}\right)$; and iowaite $\left(\mathrm{Mg}_{4} \mathrm{Fe}(\mathrm{OH})_{8} \mathrm{OCl} \times \mathrm{xH}_{2} \mathrm{O}\right)$. Iowaite, a hydroxide-chloride hydrate, is the only non-carbonate in the group. Heling and Schwarz (this volume) suggest that iowaite may be formed by the interaction of serpentine with seawater near the surface of the seamount. It is possible that takovite $\left(\mathrm{Ni}_{6} \mathrm{Al}_{2}\left(\mathrm{CO}_{3}\right)(\mathrm{OH})_{16} 4 \mathrm{H}_{2} \mathrm{O}\right)$, another sjogrenite group mineral is also present (based on the presence of peaks at $7.51,2.56,3.78 \AA$ ). Because the usual association of takovite 
is in bauxitic deposits (Bish and Brindley, 1977), the significance of its possible presence in this sample will require further investigation.

\section{Hole 779A}

Although most of the same minerals noted in Hole $778 \mathrm{~A}$ also are present in Hole 779A, lizardite appears more frequently and antigorite appears in the samples from the latter. Carbonates, both aragonite and calcite, were identified in the shallow cores. The presence of goethite was noted in the second core. Loughlinite $\left(\mathrm{Na}_{2} \mathrm{Mg}_{2} \mathrm{Si}_{6} \mathrm{O}_{16} \cdot\left(8 \mathrm{H}_{2} \mathrm{O}\right)\right.$ is present in Sample 125-779A-5R-3, 46-56 cm. A search for peaks indicating sepiolite, to which loughlinite is leached in fresh water or converts upon exposure to Mg-salt solutions (Fahey etal., 1960), suggests that mineral probably is absent in the sample. Only one of the two $\mathrm{I}_{1}=$ 100 peaks $(4.52 \AA)$ characteristic of sepiolite is present in the pattern, and that is shared with chrysotile. None of the other peaks indicative of sepiolite are present. Furthermore, the pattern generally lacks the broadened spectrum characteristic of sepiolite-bearing samples.

The two deepest cores sampled have complex patterns, indicating a more diverse mineralogy than any of the other samples from cores in this hole. Greenalite, the iron-rich serpentine group is probably present, although less abundant than chrysotile. An orthopyroxene is present, probably an iron-rich member of the group. A magnesiumrich amphibole was identified from Sample 125-779A-36R-2 (135$150 \mathrm{~cm})$. The pattern best fits magnesioriebeckite. An iron-rich orthopyroxene, possibly eulite, is present in Sample 125-779A-37R-1 $(135-150 \mathrm{~cm})$.

\section{Hole 780A, B, C, and D}

The whole-round samples taken from the summit holes were chosen primarily to test the variation in composition of the pore waters. They were not intended to represent stratigraphic relationships between holes. The samples available for XRD analysis from the two deepest summit holes are not completely representative of the mineralogic variation with depth between them. Even so, the samples are remarkably uniform. The primary difference between the holes lies in the accessory assemblages, as shown in Table 1.

\section{Hole 783A}

The minerals identified in this hole are very similar to those from the flank sites on Conical Seamount except that there are no sjogrenite group minerals present. The samples contain a very simple assemblage of dominantly chrysotile and common serpentine accessory minerals. The possible presence of corundum and hematite in Sample $125-783 \mathrm{~A}-15 \mathrm{R}-2(140-150 \mathrm{~cm})$ represents the only departure from this simple mineralogy.

\section{Hole 784A}

The principal difference between Holes $783 \mathrm{~A}$ and $784 \mathrm{~A}$ is the ubiquitous presence of clays in the latter. The samples from this hole also contain some of the sjogrenite minerals. In two of the samples tentative identification of a tungsten-bearing phase, either wolframite $\left((\mathrm{Fe}, \mathrm{Mn}) \mathrm{WO}_{4}: 2.95,2.49,4.78,3.63,1.74 \AA\right.$, and possibly $3.74 \AA$, although masked by the broad peaks of serpentine at this angle) or wolframoixiolite $(\mathrm{Nb}, \mathrm{W}, \mathrm{Fe}, \mathrm{Mn}) \mathrm{O}_{2}: 2.95,3.63,1.74,2.44,1.48$, $2.09 \AA$, although the peaks other than that at $2.95 \AA$ are shared with serpentine, brucite, or with trevorite if the latter is present). Verification of the presence of these unusual phases must await further, detailed analysis of the samples. Julgoldite $\left(\mathrm{Ca}_{2} \mathrm{Fe}_{3} \mathrm{Si}_{3} \mathrm{O}_{11}(\mathrm{OH})_{2} \cdot \mathrm{H}_{2} \mathrm{O}\right.$ : $2.95,3.83,4.78,2.59,1.53 \AA)$, a mineral related to pumpellyite, possibly is present in one of the samples although all of the identified peaks (other than that at $2.95 \AA\left(\mathrm{I}_{1}=100\right)$ ) are shared with calcite, brucite, or chrysotile. The three major peaks for cornubite $\left(\mathrm{Cu}_{5}\left(\mathrm{AsO}_{4}\right)_{2}(\mathrm{OH})_{4}: 4.72,2.57,2.49 \AA\right)$ are present in Sample 125-
784A-40R-1 (135-150 cm), although two are shared with serpentine. Thus, according to our identification criteria, it is reported as possibly present in the sample. Further analysis will be required in order to verify the presence of this unusual mineral. A carbonate mineral is present in Sample 125-784A-43R-2 $(135-150 \mathrm{~cm})$; however, calcite is suggested only by the $I / I_{1}=100$ peak, and the pattern better represents the silica-rich carbonate spurrite $\left(\mathrm{Ca}_{5}\left(\mathrm{SiO}_{4}\right)_{2} \mathrm{CO}_{3}: 2.70\right.$, $3.02,2.64 \AA)$.

\section{DISCUSSION}

\section{Hole 778A}

The prevalence of chrysotile indicates that these serpentine deposits were formed at low temperatures and pressures. Only one of the samples is thought possibly to contain antigorite. All of the samples analyzed contained lithic fragments and it is likely that if antigorite is present in the samples, it has been derived from one of these fragments, and is not forming authigenically in the serpentine deposits. The clasts of ultramafic rocks entrained within the serpentine are described in Saboda et al. (this volume). Clasts of mafic rocks entrained within the serpentine deposits are described by Johnson (this volume). Calcite and/or aragonite were not identified in the samples analyzed for this study but were present in samples examined aboard the ship. The presence of aragonite requires that the pore fluids in the serpentine deposits be of a composition other than that of seawater. The occurrence of aragonite-bearing chimney structures at the summit of the seamount observed with ALVIN (Fryer et al., 1987, 1990) and shipboard studies of pore-fluids reported in Fryer et al. (1990), show that these fluids support the precipitation of aragonite as an authigenic mineral. Likewise, the sjogrenite group minerals (iowaite, brugnatellite, coalingite, and a Ni-bearing hydroxide carbonate hydrate) probably form as a consequence of the flux of these unusual fluids through the muds. These minerals have been reported as weathering products or low-temperature hydrothermal alteration products of serpentine (Dana and Dana, 1944; Mumpton et al., 1965; Kohls and Rodda, 1967; Dunn et al., 1979). Reevesite has been reported as occurring as a product of advanced weathering in association with ultramafic rocks (De Waal and Viljoen, 1971) and as a weathering product in association with the Wolf Creek meteorite (White et al., 1967). Desautelsite (Mn-bearing carbonate hydroxide hydrate and a Ni-bearing carbonate hydroxide hydrate were reported (Dunn et al., 1979) from the Cedar Hill mine in the San Benito Mountains of western California, a serpentinite region. Mumpton et al. (1965) reported that the nearby Coalinga serpentine body at New Idria is a source of coalingite, which occurs there to a depth of $20-30 \mathrm{ft}$ below the surface in the weathering zone. The coalingite forms at this site in situ as a replacement of and is intimately intergrown with brucite. Sufficient iron is present in the New Idria brucite to form coalingite without introduction of iron from an external source (Mumpton et al., 1965). Associated minerals within the weathering zone include an unspecified member of the hydrotalcite-pyroaurite group (a submember of the sjogrenite group), artinite, and hydromagnesite. Both of the latter two minerals appear to have precipitated directly from the $\mathrm{Mg}$-rich, $\mathrm{CO}_{2}$-rich groundwater that saturates the upper part of the serpentine at New Idria (Mumpton et al., 1965).

The major implication of the presence of these hydroxide carbonate hydrate minerals in the samples from Hole $778 \mathrm{~A}$ is that the alteration of the serpentine muds to form the minerals of this group must be taking place in situ in the edifice of the seamount. We are aware of no reports of the occurrence of these minerals in serpentine deposits from other tectonic provinces (transform faults, passive margins, deep abyssal troughs). The fresher waters, which have been suggested to have derived from the subducted slab (Fryer et al., 1990; Mottl, this volume), associated with the rising serpentine muds likely maintain the stability conditions of these minerals within the serpentine deposits. 
Table 1. Mineralogy of serpentine muds determined from XRD.

\begin{tabular}{|c|c|c|c|c|c|c|c|c|c|c|c|c|c|c|c|c|}
\hline \multirow{2}{*}{$\begin{array}{l}\text { Core, section, } \\
\text { interval }(\mathrm{cm})\end{array}$} & & \multicolumn{4}{|c|}{ Serpentine group } & \multicolumn{4}{|c|}{ Layered group } & \multicolumn{4}{|c|}{ Sjogrenite group } & \multicolumn{3}{|c|}{ Carbonate } \\
\hline & & $\mathrm{C}$ & $\mathrm{L}$ & A & G & $\mathrm{Tl}$ & Chl & $\mathrm{Bc}$ & Cly & Io & $\mathrm{Br}$ & Coa & oth & $\mathrm{Ca}$ & $\mathrm{Ar}$ & Sid \\
\hline \multicolumn{17}{|l|}{ Hole 778A } \\
\hline $1 R-1 / 145-150$ & Bulk & - & $\emptyset$ & & & & - & & - & - & & $\varnothing$ & & & & \\
\hline $1 \mathrm{R}-4 / 145-150$ & Bulk & - & & & & & & & - & & & & - & & & \\
\hline $7 \mathrm{R}-1 / 140-150$ & Bulk & - & & & & & & & - & & - & $\emptyset$ & & & & \\
\hline $11 \mathrm{R}-1 / 140-150$ & Bulk & - & & & & & & $\emptyset$ & - & & & & & & & \\
\hline $12 \mathrm{R}-1 / 140-150$ & Bulk & - & & o & & & & & & & - & o & & & & \\
\hline $13 R-1 / 140-150$ & Bulk & - & & & & - & & & • & & & & & & & \\
\hline \multicolumn{17}{|l|}{ Hole 779A } \\
\hline $2 \mathrm{R}-2 / 145-150$ & Bulk & - & & & & & - & & - & $\varnothing$ & & & & & - & \\
\hline $5 R-3 / 46-56$ & Bulk & - & & & & & - & & - & & & - & & & & \\
\hline $13 \mathrm{R}-1 / 140-150$ & Bulk & - & $\emptyset$ & 0 & & & & - & - & & & $\varnothing$ & & & & \\
\hline $18 \mathrm{R}-2 / 7-17$ & Bulk & - & $\emptyset$ & 0 & & & - & & - & & & $\tilde{\emptyset}$ & & & & \\
\hline $28 \mathrm{R}-2 / 95-105$ & Bulk & - & 0 & & & & - & - & - & & & & & & & \\
\hline $30 \mathrm{R}-1 / 140-150$ & Bulk & $\emptyset$ & & & & & $\varnothing$ & & - & & & & & & & \\
\hline $32 \mathrm{R}-2 / 0-10$ & Bulk & - & & & & & & & $\varnothing$ & & & & & & & \\
\hline $34 \mathrm{R}-1 / 111-121$ & Bulk & - & $\emptyset$ & & & & & & - & & & $\emptyset$ & & & & \\
\hline $36 \mathrm{R}-2 / 135-150$ & Bulk & $\emptyset$ & & & - & & - & - & - & & & & & & & \\
\hline $37 \mathrm{R}-1 / 135-150$ & Bulk & - & $\emptyset$ & & & & - & - & & & & & & & & \\
\hline \multicolumn{17}{|l|}{ Hole 780A } \\
\hline $1 \mathrm{H}-1 / 45-55$ & Bulk & - & & & & & & - & - & - & & & & & $\varnothing$ & \\
\hline $1 \mathrm{H}-1 / 95-105$ & Bulk & - & & & & & & - & - & & - & & - & & & \\
\hline $1 \mathrm{H}-1 / 145-150$ & Bulk & - & & & & & & & & & & & - & & & \\
\hline $1 \mathrm{H}-2 / 57-67$ & Bulk & - & & & & & & & - & & & & - & & - & \\
\hline IH-2/57-67 & Bulk & - & & & & & & & - & $\bullet$ & & & - & & $\bullet$ & \\
\hline \multicolumn{17}{|l|}{ Hole 780B } \\
\hline $1 \mathrm{R}-6 / 106-116$ & Bulk & - & & & & & & $\bullet$ & - & $\bullet$ & & & $\bullet$ & & - & - \\
\hline \multicolumn{17}{|l|}{ Hole $780 \mathrm{C}$} \\
\hline $1 \mathrm{R}-3 / 140-150$ & Bulk & - & - & & & & & & - & - & & & & & o & • \\
\hline $5 R-1 / 48-58$ & Bulk & - & & & & & & - & & - & & & & & & \\
\hline $15 R-1 / 38-48$ & Bulk & - & & & & & & - & & - & & & & - & & \\
\hline \multicolumn{17}{|l|}{ Hole 780D } \\
\hline $1 \mathrm{X}-2 / 96-106$ & Bulk & - & & & & & & & - & - & & & & $\emptyset$ & & $\emptyset$ \\
\hline $1 X-3 / 68-78$ & Bulk & - & & & & & & & - & - & & & & o & & o \\
\hline $2 X-1 / 40-50$ & Bulk & - & & & & & & & $\varnothing$ & - & & & & - & & - \\
\hline $6 \mathrm{X}-1 / 68-78$ & Bulk & - & & & & & & - & - & - & & & & & & \\
\hline $7 X-5 / 135-150$ & Bulk & - & & & & & & - & - & - & & & & & & \\
\hline \multicolumn{17}{|l|}{ Hole 783A } \\
\hline $15 \mathrm{R}-2 / 140-150$ & Bulk & - & & & & & & & & & & & & & & \\
\hline $16 \mathrm{R}-2 / 135-150$ & Bulk & - & $\varnothing$ & & & & & $\varnothing$ & & & & & & & o & \\
\hline $17 \mathrm{R}-1 / 140-150$ & Bulk & - & $\varnothing$ & & & & & & & & & & & & & \\
\hline \multicolumn{17}{|l|}{ Hole 784A } \\
\hline $35 \mathrm{R}-1 / 135-150$ & Bulk & - & $\varnothing$ & & & & $\bullet$ & $\bullet$ & - & & & & & & - & \\
\hline $39 R-2 / 0-15$ & Bulk & - & & & & & & & - & & $\varnothing$ & & & & & \\
\hline $40 \mathrm{R}-1 / 135-150$ & Bulk & - & & & & & & & - & & & & $\emptyset$ & & & \\
\hline $41 \mathrm{R}-1 / 92-107$ & Bulk & - & $\emptyset$ & & & & & & - & & & & & & & \\
\hline $42 \mathrm{R}-1 / 135-150$ & Bulk & - & & & & & & & - & & & - & - & & & \\
\hline $43 R-2 / 135-150$ & Bulk & - & $\emptyset$ & & & & & & • & & & & & & $?$ & \\
\hline
\end{tabular}

Note: = definitely present; $\emptyset=$ probably present; $\mathrm{o}=$ possibly present. $\mathrm{CL}=$ chrysotile; $\mathrm{L}=$ lizardite; $\mathrm{A}=$ antigorite; $\mathrm{G}=$ greenalite; $\mathrm{Tl}=$ talc; $\mathrm{Chl}=$ chlorite; $\mathrm{Bc}=$ brucite; $\mathrm{Cly}=$ clay; $\mathrm{lo}=$ iowaite;

$\mathrm{Br}=$ brugnatenite $\mathrm{Coa}=$ coalingite; oth $=$ other sjorgrenite group minerals; $\mathrm{Ca}=$ calcite; $\mathrm{Ar}=$ argonite; $\mathrm{Sid}=$ siderite; $\mathrm{Ol}=$ olivine; $\mathrm{Opx}=$ orthopyroxene; $\mathrm{Sp}=$ spinel; $\mathrm{Gar}=$ garnet; $\mathrm{Ep}=$ epidote;

$\mathrm{Am}=$ amphibole $; \mathrm{Go}=$ goethite $\mathrm{Lo}=$ loughlinite $\mathrm{C}=$ chaoite; $\mathrm{Mt}=$ magnetite; $\mathrm{Chr}=$ chromite; $\mathrm{Oth}=$ other opaques. 
Table 1 (continued).

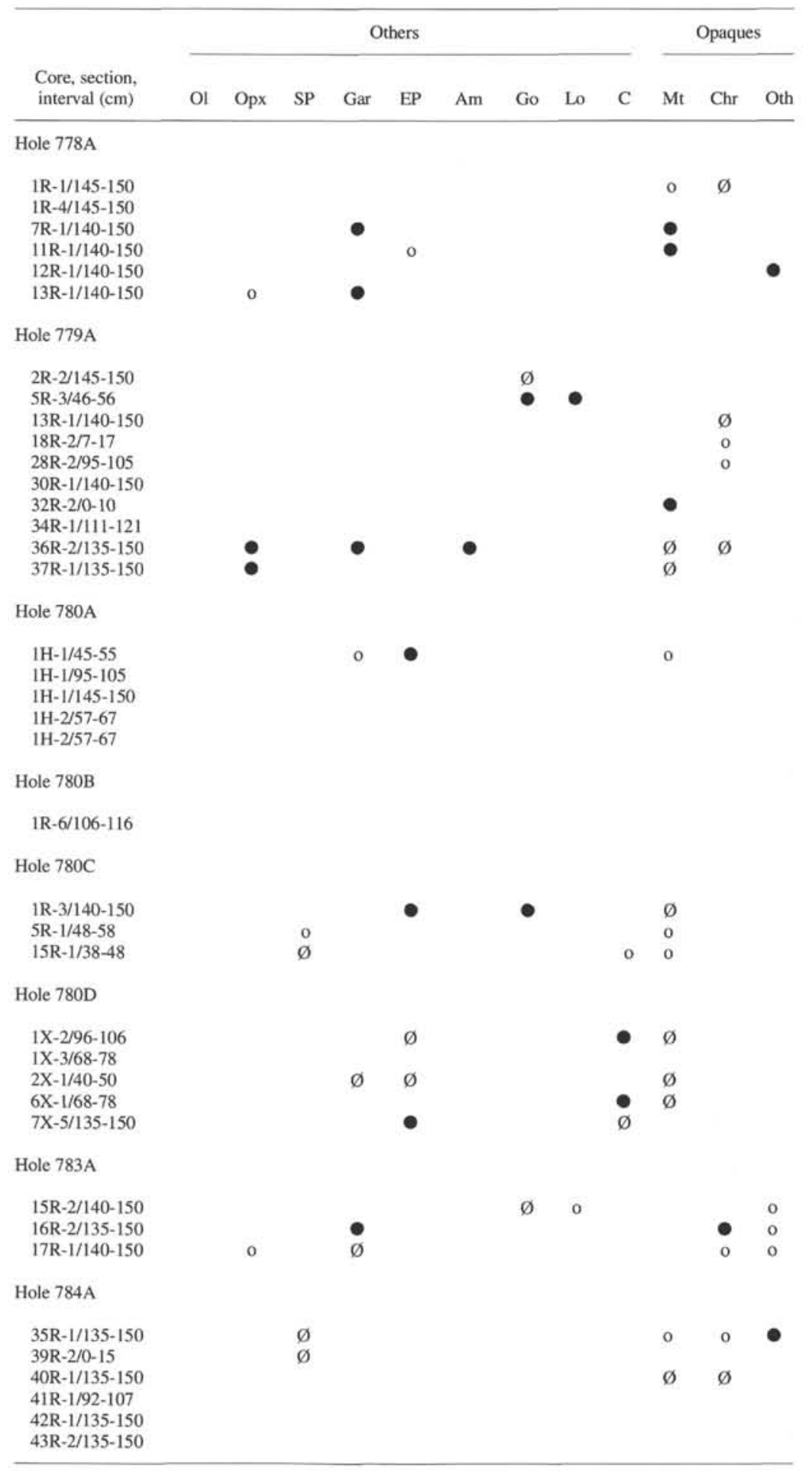


Note that fossiliferous material (foraminifers, nannofossils, silicoflagellates, and/or sponge spicules) was identified in smear slides through Core $125-778 \mathrm{~A}-4 \mathrm{R}$ in this hole (to about $30 \mathrm{mbsf}$ ). Cores $125-778 \mathrm{~A}-5 \mathrm{R}$ to $-9 \mathrm{R}$ were barren. The presence of the biogenic components may reflect admixture of pelagic materials from the seafloor interface as a consequence of drilling disturbance. If drilling disturbance were the source of the biogenic material in the deeper cores, however, the type of materials present might be expected to show greater uniformity than was observed. We suggest that serpentine deposits in the upper $30 \mathrm{~m}$ of the section at this site are intercalated with pelagic sediments. An examination of the smear-slide descriptions shows a change to a more diverse lithology of the deposits at a depth of 90 mbsf, beginning in Core 125-778A-12R. This gross lithology diversity reflects a change in the mineralogic composition of the serpentine at that depth on the south flank of the seamount and probably indicates a break in units within the serpentine deposits (Fig. 6). A detailed examination of the deposits and the geochemistry of minute rock clasts incorporated within the serpentine of Hole $778 \mathrm{~A}$, undertaken by Lagabrielle et al. (this volume), corroborates the interpretation of a three-unit stratigraphy for the hole.

\section{Hole 779A}

Chrysotile is the main serpentine mineral in this hole. Pelagic sediments and biogenic material are present in the first core $(0$ $1.1 \mathrm{mbsf}$ ) and are absent from the cores until a depth of about 216 mbsf. The presence in Core 125-779A-5R (29.6-39.1 mbsf) of loughlinite, which readily leaches to sepiolite in freshwater or in $\mathrm{Mg}$-salt solutions in a matter of days in the laboratory (Fahey et al., 1960). probably indicates that conditions favoring the stability of loughlinite are preserved in the hole. Loughlinite was first described as a vein-filling mineral in dolomitic oil shales in Wyoming by Fahey et al. (1960), and its presence in the serpentine samples of this hole may be related to the presence of the hydrocarbons identified in the pore water samples (Fryer, Pearce, Stokking, et al., 1990). Studies of the pore waters from Hole $779 \mathrm{~A}$ indicate that seawater may circulate through the seamount, but predominantly on the flanks (Mottl, this volume). Circulation of seawater through the flanks might be expected to facilitate the conversion of loughlinite to sepiolite. Note that sepiolite was not detected in any of the samples from the cores on Conical Seamount.

An increase in the diversity of the mineralogy of the cores beginning with Core 125-779A-6R (39.1 mbsf), as observed aboard ship from examination of smear slides, may indicate a change in the lithology (Fig. 7) of the flow units that persists to at least a depth of 69 mbsf (Core 125-779A-9R). Core 125-779A-10R lacks serpentine muds, but in Cores 125-779A-11 R and 125-779A-13R (106$116 \mathrm{mbsf}$ ), the lithology is apparently less diverse than in the overlying unit. We suggest that distinct units may exist from about 39 to 69 mbsf and from 69 to $116 \mathrm{mbsf}$

Lizardite and possibly antigorite occur only below depths of about 116 mbsf. The appearance of these serpentine minerals probably represents either a change in the degree of interaction of pore fluids with the matrix or a change in the lithology of the source material of the serpentine deposits that constitute the intervals below this depth. Thus, we suggest a unit from about 116 to 216 mbsf.

The lithology of the hole changes at about $216 \mathrm{mbsf}$ in Core 125-779A-27R with the reappearance of biogenic material. Kerogen was described from Cores 125-779A-27R, 125-779A-28R, and 125779A-32R, and nannofossils were identified in the smear slides (Fryer, Pearce, Stokking, et al., 1990). The presence of this material suggests a unit from 216 to 303 mbsf characterized by an interval of intercalated serpentine deposits and pelagic sediments. This stratigraphy implies a slower rate of emplacement of the serpentine deposits than is suggested by the overlying units.
Beginning at a depth of about 303 mbsf (in Cores 125-779A-36R and $125-779 \mathrm{~A}-37 \mathrm{R}$ ), the serpentine deposits comprise a more diverse mineralogy than in any of the shallower units. Amphibole, undetected in the XRD analysis of any other of our samples from Conical Seamount, is present in Core 125-779A-36R, and greenalite, the rare Fe-rich serpentine mineral, is probably present in the sample analyzed. Extant orthopyroxene is present in the sample, probably from relatively unserpentinized lithic fragments.

The changes in mineralogy represented by the analyses of the samples analyzed by XRD from the squeeze cakes are subtle. Those changes, in addition to the shipboard observations of differences in lithology and structures of the cores, suggest possibly six units are present in the material drilled on the southeast flank of the seamount in Hole 779A. We envision these units as composed of a series of serpentine mud flows that protruded, after the manner postulated by Lockwood (1972), from the summit region of the seamount in pulses of activity. These pulses varied from those having relatively high protrusion rates, as in the shallower four units, to low rates, as in the unit from 216 to $303 \mathrm{mbsf}$. The general lithologic pattern in the two flank sites suggests that a direct correlation between the flow units (as described here) is difficult to establish. Possibly the 0-30 mbsf unit of Hole $778 \mathrm{~A}$ represents a recent pulse of activity on the seamount and the 30-90 mbsf unit at Hole 778 A might be correlated lithologically with the units from 0 to $39 \mathrm{mbsf}$ of Hole 779A. The units containing the more diverse mineralogy 90-108+ mbsf (Hole 778A) and 39-216 mbsf may correspond. A more thorough study will be required to determine exact correlations and to describe in detail the variations in mineralogy of the serpentine flow units.

Conical Seamount is located at the intersection of at least two major fault zones (Fryer and Fryer, 1987; Newsom and Fryer, 1987, Marlow et al., 1990; Fryer, this volume). It is likely that periodic protrusions are related to the movement of faults underlying the seamount and therefore the source materials of the flow units may vary corresponding to the region of the fault along which the bulk of the movement takes place. The muds may be produced as a consequence of the mobilization of fault gouge by the escape of deep-seated fluids along active fault planes. We suggest that the variability of the mineralogy and lithology of the flows reflects heterogeneities within the forearc lithosphere.

\section{Holes 780A, B, C, D}

The site of Holes 780A through D is near the suspected conduit region of the seamount (Fryer et al., 1990; Fryer, this volume). Mineralogic differences between the samples from the summit holes suggest a spatial variation in the composition of the serpentine deposits near the conduit. Only two of the summit holes (780C and $780 \mathrm{D})$ penetrated to significant depth. The absence of variation in mineralogy, lithology, and structure with depth in these two deeper holes supports our interpretation that there are small-scale $(150 \mathrm{~m})$ heterogeneities in the deposits.

The first core in each of the holes contains biogenic components, as identified from shipboard examination of smear slides. In Hole $780 \mathrm{C}$, the second core also contains biogenic components, but all deeper cores are barren. There is an increase in the diversity of the lithology of the clay-and silt-sized serpentine, based on the shipboard descriptions of the smear slides, beginning in Core $125-780 \mathrm{C}-12 \mathrm{R}$ at a depth of about $100 \mathrm{mbsf}$. It is possible that this change in lithology marks a boundary between two compositional units within the hole (Fig. 8). The presence of iowaite $\left(\mathrm{Mg}_{4} \mathrm{Fe}(\mathrm{OH})_{8} \mathrm{OCl} \times \mathrm{xH}_{2} \mathrm{O}\right)$ is of interest because it provides a site for the uptake of $\mathrm{Cl}$ from pore waters in the muds. The pore fluids are remarkably depleted in $\mathrm{Cl}$ (Fryer et al., 1990; Fryer, Pearce, Stokking, et al., 1990; Mottl, this volume), and if depletion were not a primary characteristic of the fluids, there should be a phase present in the muds to provide a site for the $\mathrm{Cl}$. Both 
the rarity of iowaite and the absence of any other mineral that contains $\mathrm{Cl}$ support the interpretation that low chlorinity of pore-fluids is a primary characteristic (Mottl, this volume), and that interaction of the serpentine with seawater is responsible for formation of the iowaite (Heling and Schwarz, this volume).

\section{Hole 783A}

Our observations of the mineralogy, lithology, and structure of the serpentine deposits from both holes drilled on Torishima Forearc Seamount in the Izu-Bonin forearc region suggest a different history from that of the serpentine deposits from Conical Seamount on the Mariana forearc region. The serpentine deposits from Torishima Forearc Seamount are certainly more highly compacted. Thus, their rheological properties are very different from those at the summit of Conical Seamount. Hole 783A was drilled on the eastern flank of the seamount where the contact between the overlying pelagic sediments and the serpentine deposits was recovered. Core 125-783A-14R, at the contact between the serpentine units and the overlying pelagic sediments, contains biogenic components (radiolarians) only in the first few centimeters. The deeper intervals in this and the remainder of the cores in the hole are barren. Therefore, it is unlikely that the serpentine unit is intercalated with sediments. The mineralogy of the samples in the serpentine muds varies little with depth and may represent a single event. If the presence of sjogrenite group minerals indicates interaction with subduction related fluids, then these deposits do not appear to have done so. This observation and the lack of mineralogic variability, suggesting the probable existence of only one unit in the recovered interval, implies that these deposits may represent a slump deposit, rather than a series of mud flows (Fig. 9).

\section{Hole 784A}

The serpentine deposits recovered from the western flank of Torishima Forearc Seamount are similar to those from Hole 783A in the first few cores below the contact with the overlying pelagic sediment (Cores 125-784A-35R-40R: 319-377 mbsf). Beginning with Core 125-784A-41R ( $377 \mathrm{mbsf}$ ) and persisting through at least Core 125-784A-43R (406 mbsf), the deposits are less diverse mineralogically. It is possible that there are two units present in this hole (see Fig. 10).

The presence of the sjogrenite minerals in the serpentine samples from this hole suggest that fluids other than seawater possibly have interacted with the serpentine deposits at this site as they probably have in the sites on Conical Seamount. It is unlikely that serpentine deposits are being produced at the summit of this seamount (Marlow, et al., 1990). The deposits recovered during drilling are at least $10 \mathrm{~m} . \mathrm{y}$. old (Fryer, Pearce, Stokking, et al., 1990). The seamount has been suggested to have formed by a combination of vertical tectonic movement along faults at the periphery of the edifice as well as possibly by build-up of serpentine mud flows (Horine et al., 1990). If the vertical tectonic movement is still active at the fault boundaries of the seamount, it is possible that deep-seated fluids may migrate up along those fault planes and interact with older flow and/or debris deposits. Studies of the pore fluids in the samples from this seamount (Mottl, this volume) show none of the characteristics of the probably subduction related fluids apparent at the Conical Seamount sites. Therefore, it is unlikely that slab-related fluids are currently associated with these deposits. Such fluids may have interacted with the deposits in the past, as suggested by the presence of the sjogrenite minerals found in the samples from this hole. Clearly, further investigation of the tectonic activity in the forearc region will be required, to demonstrate the degree of seismic activity of this region. The analyses of the pore waters taken from the samples analyzed for this study show none of the characteristics of the deep-seated fluid apparent in the
Conical Seamount pore water samples. Therefore, it is unlikely that slab-related fluids are currently influencing the water-rock interactions in the serpentines of Sites 783 and 784 . The nature of the serpentine deposits and the composition of the fluids with which they are associated demonstrate that serpentinization can continue in situ in serpentine debris deposits, as seawater interacts with these deposits.

\section{CONCLUSIONS}

The silt- and clay-sized serpentine recovered from both Conical Seamount on the Mariana forearc region and Torishima Forearc Seamount on the Izu-Bonin forearc region is remarkably uniform in composition. The dominant mineral present is chrysotile. In Conical Seamount at least some of the chrysotile is forming in situ as silt- and clay-sized serpentine interacts with seawater and another fluid, possibly derived from the subducted slab. Serpentinization processes are also active within the deposits on Torishima Forearc Seamount, however the associated fluids are currently seawater. The presence of several minerals from the sjogrenite group in samples from both seamounts is consistent with the interaction of these fine-grained serpentine deposits with a fluid other than seawater at some point in their formation.

Subtle distinctions in mineralogy attest to the presence of varying numbers of units in each of the holes drilled. These units are likely the result of periodic protrusion of flows of serpentine muds or episodes of debris flow formation on the flanks of the seamounts.

There are numerous examples of sedimentary serpentinite deposits around the Pacific, in the Mediterranean, and the Caribbean areas (Lockwood, 1971). Several of these are very similar to the deposits forming on Conical Seamount and are represented by the older deposits at Torishima Forearc Seamount. We suggest that Conical Seamount may represent a type locality for the study of in situ formation of many of these sedimentary serpentinite bodies and that serpentinization can continue in situ in serpentine debris deposits, particularly if subduction related fluids are interacting with these deposits.

\section{ACKNOWLEDGMENTS}

We thank R. G. Coleman for supplying samples of serpentine for use as standards in our analyses and W. Shibata for sample preparation and analysis. We are grateful for comments on these interpretations from D. Heling and Y. Lagabrielle and reviews of this manuscript by V. Kulm and F. Wicks. This work was supported by a grant from the United States Science Advisory Committee of the Joint Oceanographic Institutions Inc. This is School of Ocean and Earth Science and Technology contribution no. 2638 and Planetary Geosciences contribution no. 660 .

\section{REFERENCES}

Berger, W. H., 1970. Planktonic foraminifera: selective solution and the lysocline. Mar. Geol., 8:111-138.

Berner, R. A., and Honjo, S., 1981. Pelagic sedimentation of aragonite: its geochemical significance. Science, 211:940-942.

Bish, D. L., and Brindley, G. W., 1977. A reinvestigation of Takovite, a nickel aluminum hydroxy-carbonate of the pyroaurite group. Am Mineral., 62:458-464.

Bloomer, S., 1982. Structure and evolution of the Mariana Trench, petrologic and geochemical studies [Ph.D. dissert.]. Univ. California, San Diego.

Bloomer, S. H., and Hawkins, J. W., 1983. Gabbroic and ultramafic rocks from the Mariana Trench: an island arc ophiolite. In Hayes D. E. (Ed.), The Tectonic and Geologic Evolution of Southeast Asian Seas and Islands (Pt. 2). Am. Geophys. Union, Geophys. Monogr. Ser., 27:294-317.

Carlson, C., 1984. Stratigraphic and structural significance of foliate serpentine breccias, Wilbur Springs. Soc. Econ. Paleontol. Mineral., Field Trip Guidebook, 3:108-112.

Dana, J. D., and Dana, E. S., 1944. The System of Mineralogy (Vol. 2): New York (Wiley). 
De Waal, S. A., and Viljoen, E. A., 1971. Nickel minerals from Barberton, South Africa: IV. Reevesite, a member of the hydrotalcite group. Am. Mineral., 56:1077-1081.

Dunn, P. J., Peacor, D. R., Palmer, T. D., 1979. Desautelsite, a new mineral of the pyroaurite group. Am. Mineral., 64:127-130.

Fahey, J. J., Malcolm, R., Axelrod, J. M., 1960. Loughlinite, a new hydrous sodium magnesium silicate. Am. Mineral., 45:270-281.

Fryer, P., Ambos, E. L., and Hussong, D. M., 1985. Origin and emplacement of Mariana forearc seamounts. Geology, 13:774-777.

Fryer, P., and Fryer, G. J., 1987. Origins of non-volcanic seamounts in a forearc environment. In Keating, B. H., Fryer, P., Batiza, R., and Boehlert, G. W. (Eds.), Seamounts Islands and Atolls. Am. Geophys. Union, Geophys. Monogr. Ser., 43:61-72.

Fryer, P., Haggerty, J., Tilbrook, B., Sedwick, P., Johnson, L. E., Saboda, K. L., Newsom, S. Y., Karig, D. E., Uyeda, S., and Ishii, T., 1987. Results of studies of Mariana forearc serpentinite diapirism. Eos, 68:1534.

Fryer, P., Pearce, J. A., Stokking, L. B., et al., 1990. Proc. ODP, Init. Repts., College Station, TX (Ocean Drilling Program).

Fryer, P., Saboda, K. L., Johnson, L. E., MacKay, M. E., Moore, G. F., and Stoffers, P., 1990. Conical Seamount: SeaMARC II, Alvin submersible, and seismic reflection studies. In Fryer, P., Pearce, J. A., Stokking, L. B., et al., Proc. ODP, Init. Repts., 125: College Station, TX (Ocean Drilling Program), 69-80.

Fryer, P., and Smoot, N. C., 1985. Morphology of ocean plate seamounts in the Mariana and Izu-Bonin subduction zone. Mar. Geol., 64:77-94.

Honza, E., and Tamaki, K., 1985. The Bonin Arc. In Nairn, A.E.M., and Uyeda, S. (Eds.), The Ocean Basins and Margins (Vol. 7): The Pacific Ocean: New York (Plenum Press), 7:459-502.

Horine, R. L., Moore, G. F., and Taylor, B.,1990. Structure of the outer Izu-Bonin forearc from seismic-reflection profiling and gravity modeling. In Fryer, P., Pearce, J. A., Stokking, L. B., et al., Proc. ODP, Init. Repts., 125: College Station (Ocean Drilling Program), 81-94.

Hussong, D. M., and Fryer, P., 1985. Forearc tectonics in the northern Mariana arc. In Nasu, N. (Ed.), Formation of Active Ocean Margins: Tokyo (Terra Scientific), 273-290.

JCPDS, 1980. Mineral Powder Diffraction File Search Manual: Swarthmore, PA (Int. Cent. for Diffraction Data),

Kobayashi, K. (Ed.), 1989. Preliminary Report of the Hakuho Maru Cruise KH-87-3, July-August 13, 1988, Izu-Ogasawara (Bonin) East Mariana Basin and Yap Trench (WESTPAC, ODP Site Survey). Ocean Res. Inst., Univ. Tokyo.
Kohls, D. W., and Rodda, J. L., 1967. Iowaite, a new hydrous magnesium hydroxide-ferric oxychloride from the precambrian of Iowa. Am. Mineral., 52:1261-1271.

LaGabrielle, Y., Whitechurch, H., Marcoux, J., Juteau, T., Reuben, I., and Guillocheau, F., 1986. Obduction related ophiolitic polymict breccias covering the ophiolites of Antalya (S.W. Turkey). Geology, 14:734-737.

Li, Y.-H., Takahashi, T., and Broecker, W. S., 1969. Degree of saturation of calcium carbonate in the oceans. J. Geophys. Res., 75:5507-5525.

Lockwood, J. P., 1971. Sedimentary and gravity slide emplacement of serpentinite. Geol. Soc. Am. Bull., 82:919-936.

, 1972. Possible mechanisms for the emplacement of Alpine-type serpentine. Mem. - Geol. Soc. Am., 132:273-287.

Manheim, F. T., and Sayles, F. L., 1974. Composition and origin of interstitial waters of marine sediments based on deep sea drill cores. In Goldberg, E. D. (Ed.), The Sea (Vol. 5): New York (Wiley), 527-568.

Marlow, M. S., Merrill, D. L., and the ODP Leg 125 Shipboard Scientific Party, 1990. Underway geophysics. In Fryer, P., Pearce, J. A., Stokking, L. B., et al., Proc. ODP, Init. Repts., 125: College Station, TX (Ocean Drilling Program), 41-67.

Mumpton, F. A., Jaffe, H. W., and Thompson, C. S., 1965. Coalingite, a new mineral from the New Idria serpentinite, Fresno and San Benito Counties, California. Am. Mineral., 50:1893-1913.

Newsom, S. Y., and Fryer, P., 1987. Three-dimensional gravity modeling of serpentinite seamounts in the Mariana forearc. Eos, 68:1534.

Phipps, S. P., 1984. Ophiolitic olistostromes in the basal Great Valley sequences, Napa County, northern California Coast Ranges. Spec. Pap.Geol. Soc. Am., 198:103-125.

Saboda, K. L., 1991. Petrology of ultramafic rocks from Conical Seamount based on Alvin Submersible and Ocean Drilling Program Studies [M.S. thesis]. Univ. of Hawaii, Honolulu.

Saboda, K. L., Fryer, P., and Fryer, G., 1987. Preliminary studies of metamorphic rocks collected during Alvin studies of Mariana forearc seamounts. Eos, 68:1534.

White, J. S., et al., 1967. Secondary minerals produced by weathering of the Wolf Creek meteorite. Am. Mineral., 52:1190-1197.

Date of initial receipt: 5 October 1990

Date of acceptance: 8 October 1991

Ms 125B-126 


\section{APPENDIX A}

\section{Criteria for Distinguishing Serpentine Phases by XRD}

Table 1. XRD peaks useful for distinguishing chrysotile or lizardite (vs. antigorite).

\begin{tabular}{|c|c|c|}
\hline$d(A)$ & $2 \theta$ & Comments \\
\hline $4.55-4.63$ & $19.17-19.51$ & $\begin{array}{l}\text { Presence indicates chrysotile (i } 40 \text { ) or lizardite } \\
(\mathrm{i} \sim 35) \text {; very low (i } 2 \text { ) in antigorite. }\end{array}$ \\
\hline $2.655-2.668$ & $33.59-33.76$ & $\begin{array}{l}\text { Presence indicates chrysotile (i } 20 \text { ) of lizardite } \\
\text { (i 10); absent in antigorite (not present in our } \\
\text { standard for chrysotile). }\end{array}$ \\
\hline $2.588-2.617$ & $34.26-34.66$ & $\begin{array}{l}\text { Presence indicates chrysotile (i - 20) or lizardite } \\
\text { (i-10); absent in antigorite (not present in our } \\
\text { standard of chrysotile). }\end{array}$ \\
\hline $2.332-2.37$ & $37.96-38.61$ & $\begin{array}{l}\text { Presence indicates chrysotile (i } 20 \text { ) or lizardite } \\
\text { (i } 30 \text { ); absent in antigorite (not present in our } \\
\text { standards for chrysotile or lizardite). }\end{array}$ \\
\hline $1.962-1.966$ & $64.17-46.27$ & $\begin{array}{l}\text { Presence indicates chrysotile (i } 10 \text { ) or lizardite } \\
\text { (i } \sim 30) \text {; absent in antigorite (not present in our } \\
\text { standard chrysotile or lizardite). }\end{array}$ \\
\hline $1.738-1.748$ & $52.34-52.66$ & $\begin{array}{l}\text { Presence indicates chrysotile }(\mathrm{i} \sim 10) \text { or lizardite } \\
(\mathrm{i} \sim 10) \text {; generally absent in antigorite, but present } \\
\text { in our standard antigorite (not present in our } \\
\text { standard chrysotile). }\end{array}$ \\
\hline $1.501-1.503$ & $61.72-61.81$ & $\begin{array}{l}\text { Presence indicates chrysotile ( } \mathrm{i} \sim 15) \text { or lizardite } \\
\text { (i } 40 \text { ); not present in our standard chrysotile. }\end{array}$ \\
\hline
\end{tabular}

Table 2. XRD peaks useful for distinguishing chrysotile.

\begin{tabular}{ccc}
\hline d(A) & $2 \theta$ & Comments \\
\hline 2.095 & 43.18 & Presence indicates chrysotile (i 20$)$; not present in our standard chrysotile. \\
1.644 & 55.93 & Presence indicates chrysotile (i 10); not present in our standard chrysotile. \\
1.362 & 68.94 & Presence indicates chrysotile (i 25); not present in our standard chrysotile. \\
\hline
\end{tabular}

Table 3. XRD peaks useful for distinguishing lizardite.

\begin{tabular}{|c|c|c|}
\hline$d(A)$ & $2 \theta$ & Comments \\
\hline 3.89 & 22.86 & Presence indicates lizardite (i 1-30). \\
\hline 3.34 & 26.69 & Presence indicates lizardite $(\mathrm{i} \sim 10)$. \\
\hline 2.85 & 31.39 & Presence indicates lizardite $(\mathrm{i} \sim 10)$. \\
\hline $2.145-2.169$ & $41.64-42.13$ & $\begin{array}{l}\text { If large, suggests lizardite (i } 60 \text { ); small in antigorite } \\
\text { (i } \sim 5 \text { ) and chrysotile (i }-5 \text {; not present in our } \\
\text { standard chrysotile). }\end{array}$ \\
\hline $1.79-1.792$ & $50.96-51.02$ & Presence indicates lizardite $(\mathrm{i} \sim 10-40)$ \\
\hline 1.701 & 53.9 & $\begin{array}{l}\text { Presence indicates lizardite ( } \mathrm{i} \sim 10) \text {; not present in } \\
\text { our standard lizardite, possibly present in our } \\
\text { standard antigorite. }\end{array}$ \\
\hline 1.418 & 65.87 & $\begin{array}{l}\text { Presence indicates lizardite ( } \mathrm{i} \sim 10) \text {, but not present } \\
\text { in our standard lizardite. }\end{array}$ \\
\hline 1.381 & 67.87 & $\begin{array}{l}\text { Presence indicates lizardite ( } \mathrm{i}-10 \text { ), but not present } \\
\text { in our standard lizardite. }\end{array}$ \\
\hline
\end{tabular}

Table 4. XRD peaks useful for distinguishing antigorite.

\begin{tabular}{|c|c|c|}
\hline$d(A)$ & $2 \theta$ & Comments \\
\hline 6.88 & 12.87 & $\begin{array}{l}\text { Presence indicates antigorite ( } \mathrm{i} \sim 1 \text { ), but not present in } \\
\text { our standard antigorite. }\end{array}$ \\
\hline 6.42 & 13.79 & $\begin{array}{l}\text { Presence indicates antigorite (i 1), but not present in } \\
\text { our standard antigorite. }\end{array}$ \\
\hline $3.53-3.66$ & $24.32-25.22$ & $\begin{array}{l}\text { Doublet or triplet indicates antigorite }(i \sim 2-65) \text {; } \\
\text { chrysotile }(\sim 60) \text { and lizardite }(i \sim 60) \text { have singlet. }\end{array}$ \\
\hline 1.814 & 50.3 & $\begin{array}{l}\text { Presence indicates antigorite ( } \mathrm{i} \sim 2 \text { ), but also present } \\
\text { in our standard chrysotile and lizardite. }\end{array}$ \\
\hline 1.779 & 51.36 & Presence indicates antigorite $(\mathrm{i} \sim 1)$ \\
\hline $1.558-1.56$ & $59.23-59.31$ & Presence indicates antigorite (i -3$)$. \\
\hline
\end{tabular}




\section{APPENDIX B}

Observed 2d-Spacing and Relative Intensities for Principal XRD Peaks Used to Identify Minerals

Table 1. Major XRD peaks used to identify minerals other than serpentine.

\begin{tabular}{|c|c|c|c|c|c|c|c|c|c|c|}
\hline Mineral name (comments) & $2 d$ & Int. & $2 \mathrm{~d}$ & Int. & $2 d$ & Int. & $2 \mathrm{~d}$ & Int. & $2 \mathrm{~d}$ & Int. \\
\hline Loughlinite & 12.93 & $\mathbf{x}$ & 4.35 & 20 & 4.52 & 10 & 3.63 & 10 & 2.55 & 10 \\
\hline Montmorillonite & $12.9-15.0$ & $x$ & $4.47-4.53$ & $55-80$ & 1.50 & $25-65$ & $4.97-5.01$ & $60-10$ & $2.51-2.56$ & $35-40$ \\
\hline Talc & 9.34 & $\mathrm{x}$ & 4.59 & 45 & 3.12 & 40 & 2.48 & 30 & & \\
\hline Magnesiohornblende & 8.35 & $x$ & 3.11 & 70 & 3.26 & 20 & 2.69 & 20 & & \\
\hline Iowaite & 8.11 & $\mathrm{x}$ & 4.05 & 40 & 2.64 & 18 & 2.36 & 25 & 2.02 & 20 \\
\hline Brugnatellite & 7.93 & $\mathrm{x}$ & 3.96 & 90 & 2.63 & 50 & 2.35 & 60 & 2.00 & 70 \\
\hline Takovite & 7.51 & $\mathrm{x}$ & 2.56 & 80 & 3.78 & 70 & & & & \\
\hline Cr-Clinochlore IIb* & 7.21 & $\mathrm{x}$ & 2.42 & $\mathrm{x}$ & 14.50 & 90 & 3.60 & 90 & 1.56 & 90 \\
\hline Cronstedtite (kaolinite-serp group) & 7.09 & $\mathrm{x}$ & 3.54 & 85 & 2.72 & 50 & 2.44 & 40 & & \\
\hline Chamosite IIb* (chlorite group) & 7.08 & $\mathrm{x}$ & 14.00 & 60 & 3.53 & 50 & 4.68 & 30 & 2.62 & 30 \\
\hline Amesite (kaolinite-serp group) & 7.06 & $\mathrm{x}$ & 3.52 & $\mathrm{x}$ & 1.93 & 70 & 1.46 & 60 & 2.48 & 60 \\
\hline Chamosite IIb (chlorite group) & 7.05 & $\mathrm{x}$ & 3.53 & 80 & 2.52 & 50 & 14.10 & 40 & 4.71 & 40 \\
\hline Nordstrandite & 4.79 & $x$ & 4.32 & 30 & 2.27 & 30 & 2.39 & 30 & 2.02 & 30 \\
\hline Comubite & 4.72 & $\mathrm{x}$ & 2.57 & $\mathrm{x}$ & 2.49 & $\mathrm{x}$ & 2.69 & 90 & 3.49 & 80 \\
\hline Chaoite & 4.47 & $\mathrm{x}$ & 4.26 & $\mathrm{x}$ & 4.12 & 80 & 3.03 & 60 & 2.55 & 60 \\
\hline Nacrite & 4.35 & 80 & 3.62 & 80 & 7.19 & $\mathrm{x}$ & 2.44 & 60 & 4.41 & 30 \\
\hline Illite & 4.43 & $\mathrm{x}$ & 2.56 & 90 & 3.66 & 40 & 3.06 & 40 & 1.50 & 40 \\
\hline Goethite & 4.18 & $\mathrm{x}$ & 2.69 & 30 & 2.45 & 25 & 1.72 & 20 & 2.49 & 15 \\
\hline Reevesite & 3.80 & $\mathrm{x}$ & 2.60 & 50 & 7.60 & $\mathrm{x}$ & 2.30 & 40 & 1.95 & 40 \\
\hline Anhydrite & 3.49 & $\mathrm{x}$ & 2.85 & 30 & 2.33 & 30 & 2.21 & 20 & 1.87 & 15 \\
\hline Aragonite & 3.40 & $\mathrm{x}$ & 1.98 & 65 & 3.27 & 50 & 2.70 & 45 & 2.37 & 40 \\
\hline Eulite & 3.22 & $\mathrm{x}$ & 2.88 & 75 & 2.51 & 55 & 1.50 & 55 & 2.58 & 50 \\
\hline Magnesioriebeckite & 3.09 & $\mathrm{~g}$ & 8.35 & $\mathrm{x}$ & 4.24 & 20 & 3.25 & 20 & & \\
\hline Calcite & $3.02-3.04$ & $\mathrm{x}$ & 2.29 & 20 & 2.10 & 20 & & & & \\
\hline Wolframite & 2.95 & $\mathrm{x}$ & 2.48 & 60 & 4.76 & 50 & 3.74 & 50 & 3.65 & 50 \\
\hline Wolframoixiolite & 2.96 & $\mathrm{x}$ & 3.64 & 70 & 1.72 & 70 & 2.49 & 60 & 1.77 & 60 \\
\hline Julgoldite & 2.95 & $x$ & 3.84 & 80 & 4.80 & 70 & 2.59 & 70 & 2.78 & 60 \\
\hline Halite & 2.82 & $\mathrm{x}$ & 1.99 & 60 & 1.63 & 20 & 3.26 & 10 & & \\
\hline Hortonolite (Fa .6) & 2.81 & $\mathrm{x}$ & 2.49 & 70 & 2.55 & 60 & 1.77 & 40 & 3.54 & 30 \\
\hline Spurrite & 2.70 & $\mathrm{x}$ & 2.64 & 70 & 3.02 & 65 & 2.66 & 50 & & \\
\hline Kaersutite & 2.69 & $\mathrm{x}$ & 3.10 & 80 & 8.38 & 70 & 3.36 & 70 & 2.55 & 70 \\
\hline Ca-rich Garnet (goldmanite or andradite) & $2.69-2.70$ & $x$ & $3.01-3.02$ & 70 & 1.61 & 50 & $2.45-2.46$ & 40 & $1.95-1.96$ & 20 \\
\hline Ca-rich Garnet (uvarovite) & 2.69 & $x$ & 3.00 & 70 & 1.61 & 60 & 2.45 & 60 & 2.36 & 30 \\
\hline Grossular & 2.65 & $\mathrm{x}$ & 1.58 & 50 & 2.60 & 25 & 1.92 & 25 & 1.64 & 25 \\
\hline Greenalite & 2.56 & $\mathrm{x}$ & 7.12 & 80 & 3.56 & 80 & 1.60 & 60 & 2.20 & 40 \\
\hline Magnetite & 2.53 & $\mathrm{x}$ & 1.62 & 30 & 1.49 & 40 & 2.97 & 30 & 2.10 & 20 \\
\hline Trevorite & 2.52 & $\mathrm{x}$ & 2.96 & 40 & 1.48 & 40 & 1.61 & 30 & 2.09 & 30 \\
\hline Chromite & $2.48-2.52$ & $\mathrm{x}$ & 1.46 & $40-90$ & $1.58-1.60$ & $35-90$ & & & & \\
\hline Spinel & 2.44 & $\mathrm{x}$ & 1.43 & $x-60$ & 2.87 & 80 & 2.02 & 60 & & \\
\hline Brucite syn & 2.37 & $\mathrm{x}$ & 4.77 & 90 & 1.79 & 55 & 1.57 & 35 & 1.49 & 20 \\
\hline Coalingite & 2.34 & $\mathrm{x}$ & 4.20 & 80 & 6.05 & 50 & 1.56 & 50 & 13.40 & 40 \\
\hline Hydrogrossular & 2.30 & $x$ & 2.04 & 95 & 5.13 & 90 & 2.81 & 80 & 3.36 & 55 \\
\hline Corundum & 2.09 & $x$ & 2.55 & 90 & 1.60 & 80 & 4.79 & 75 & 1.37 & 50 \\
\hline
\end{tabular}

Note: $2 \mathrm{~d}=$ twice the distance (in angstroms) between lattice planes in a given mineral; Int. = intensities of peaks given in \% of intensity of the major peak for the given mineral, where $\mathrm{x}=$ intensity of the major peak. Ranges are given for some minerals and are denoted by two numbers for $2 \mathrm{~d}$ separated by a dash. The intensities of the end-members of the range are given and where different are separated by a dash. 